\title{
Memoria irreverente disfrazada de Alegría. El pasado argentino reciente desde la óptica del humor gráfico (2016-2019)
}

\section{Irreverent Memory Disguised as Alegría. Argentina's recent past as portrayed in political cartoon (2016-2019)}

Laura Cristina Fernández Hernán Martignone 
Laura Cristina Fernández es doctora en Ciencias Sociales y magíster en Arte Latinoamericano por la Universidad Nacional de Cuyo (Argentina). Trabaja como profesora titular del Seminario de Tesis para la licenciatura en Artes, del taller de Dibujo III (FAD-UNCUYO), codirige un proyecto de investigación sobre fanzines y prácticas arte/política en Mendoza, Argentina, ha dictado un seminario doctoral sobre cultura visual (FCPyS- UNCUYO) e integra varios equipos de investigación relacionados con cómics y memoria reciente. Ha sido becaria doctoral y postdoctoral de CONICET, ha participado en estancias de investigación en Reino Unido y España (Marie Curie RISE- Horizon 2020), ha publicado Historieta y resistencia. Arte y politica en Oesterheld (EDIUNC, 2012) y numerosos artículos para revistas académicas. Desde 2011 ha publicado más de trece libros de historieta como autora integral o coautora en antologías, ha colaborado en las revistas Lento (Uruguay), Clitoris (Argentina) y Cthulbu (España) y ha participado en festivales de historieta en varios países. Desde hace un par de años, ha comenzado a incursionar en la escritura de ficción.

Hernán Martignone es doctor en Letras Clásicas por la Universidad de Buenos Aires (Argentina). Ha sido becario doctoral de CONICET y actualmente se desempeña como docente de griego clásico en la Facultad de Filosofía y Letras (UBA) y de latín en educación media (ILSE/CNBA). Periodista de historietas en revistas como Comiqueando, ha coescrito el libro Historietas a diario. Las tiras cómicas argentinas de Mafalda a nuestros días (con Mariano Prunes; Buenos Aires, Libraria, 2008). Ha participado en eventos nacionales e internacionales de cómic, así como en programas radiales y televisivos de divulgación (Plop, Continuará...). Traduce historietas del francés y del inglés y dirige el blog Sobre historieta (www.sobrehistorieta.wordpress.com). Además, está a cargo del proyecto «Representaciones y apropiaciones de la Antigüedad clásica en la historieta argentina» (2019-2021), financiado por el Programa de Apoyo a la Investigación de la Facultad de Filosofía y Letras (Instituto de Filología Clásica, UBA).

Fecha de recepción: 26 de septiembre de 2019

Fecha de aceptación definitiva: 2 de marzo de 2020 


\title{
Resumen
}

A partir del interrogante sobre los modos en que se construyen las memorias del pasado reciente (y) traumático, este trabajo se centra en algunas piezas de humor gráfico argentino, pertenecientes al colectivo Alegría Política (2016-). Se busca analizar los discursos presentes en estas producciones, sus posibles lecturas y resignificaciones, tomando como referencia los trabajos de Burkart (2017), Chute (2016) y Montealegre (2018). Nos preguntaremos si los trabajos de Alegría podrían ser formas no auráticas, provocadoras o irreverentes, que buscan reconstruir un «pasado reciente», ya sea cuestionando o bien reforzando ciertas creencias fundadas. Utilizaremos un abordaje heterodoxo centrado en el análisis crítico del discurso, en diálogo con los estudios sobre la memoria, con la historia social y la teoría de la comunicación situadas en nuestras realidades (pos)neoliberales, poscoloniales y críticas.

Palabras clave: Crisis, historieta argentina, humor político

\begin{abstract}
Considering the question about the ways that «recent past» memories are built, we will focus on interpreting some argentinian cartoons related to the group, or collective, named Alegria politica (2016-). We analyse the discourses, possible interpretations and re-significations around this productions, taking Burkart's (2017), Chute's (2016) and Montealegre's (2018) inquiries as references; also considering if these humor discourses expose a non-auratic, provocative or irreverent point of view about «recent past» which could lead (or intend) to criticize or to reinforce some beliefs from our society. We appeal to a heterodox perspective: a critical discourse analysis in dialogue with the studies about memory, the social history of art and the communication studies, situated on our (post)neoliberal, postcolonial and critical realities.
\end{abstract}

Keywords: Argentinian comics, crisis, political humor

\section{Cita bibliográfica}

Fernández, L. C. y Martignone, H. «Memoria irreverente disfrazada de Alegría. El pasado argentino reciente desde la óptica del humor gráfico (2016-2019)», en CuCo, Cuadernos de cómics n. 14 (2020), pp. 7-40. 


\section{Introducción}

... facit indignatio versum...

Juvenal, Sátiras, 1.79

Este trabajo tiene como punto de partida la pregunta acerca de los modos en que se construyen las memorias sobre el pasado reciente (y) traumático en el lenguaje de la historieta o cómic. En particular, decidimos aquí centrarnos en el análisis de algunas piezas de humor gráfico pertenecientes al colectivo argentino Alegría política (2016-).

Los impulsores de este proyecto han sido humoristas, ilustradores e historietistas ya conocidos en el medio, pero también se incorporaron muchos artistas amateurs o iniciados en el oficio. Este criterio amplio, de una aparente horizontalidad, libertad temática y estética, entendemos que responde a un objetivo común entre tales autores: generar un espacio de visibilidad de situaciones políticas, sociales y económicas que se han ocultado o minimizado en los grandes medios durante este período.

Es importante aclarar los motivos coyunturales de tal necesidad. La iniciativa surge en el verano posterior a la asunción presidencial de Mauricio Macri (diciembre de 2015), en un contexto de desasosiego para el campo de la historieta: la caída de varios proyectos culturales y educativos creados por la anterior gestión (NACs, ${ }^{1}$ Libros y Casas) ${ }^{2}$ tras la disolución del Ministerio de Planificación; la suba en impuestos y servicios, que afectaba incrementando los costos de producción; la crisis y el cierre de medios (que se fue profundizando en los siguientes años con el despido de trabajadores de ese sector ${ }^{3}$ y el consecuente achicamiento de los espacios para el humor gráfico

${ }^{1}$ Los Núcleos de Acceso al Conocimiento (NACs), proyecto articulado entre el Ministerio de Planificación y la Universidad de la Matanza, incluían propuestas de capacitación en oficios digitales para todo el país, especialmente en ciudades y pueblos donde el acceso a dichos saberes era restringido. Así, durante 2015, se realizaron talleres sobre historieta e ilustración y entintado y color digital en ciudades desde el norte a la Patagonia. Tal proyecto fue cancelado en enero de 2016.

2 «Libros y Casas» fue un proyecto articulado con el Plan Procrear. Se trataba de ofrecer una biblioteca de autores argentinos a cada hogar, que incluía adaptaciones de cuentos y novelas a historieta. Las producciones eran realizadas especialmente para este proyecto, lo cual implicaba trabajo y visibilidad para algunos historietistas jóvenes.

3 Uno de los casos más resonantes fue el cierre, a fines de marzo de 2016, del suplemento HN (Historietas Nacionales) de la Agencia Télam (la Agencia Nacional de Noticias), que había comenzado en 2011 y empleaba a muchos historietistas, dibujantes y humoristas gráficos. Tenía una línea editorial claramente «nacional y popular», por lo cual fue perseguida por los sectores antiperonistas. 
y la historieta); y, por último, para una gran parte del campo intelectual, la sensación de una derrota político-cultural a la cual no se le encontraba una explicación concreta. ${ }^{4}$ Esta conjugación de situaciones críticas convocó a varios dibujantes a utilizar como referente para este proyecto de humor político la consigna paradojal, engañosa o fraudulenta (según el rigor con el que se la juzgue) de la campaña de Cambiemos: «la revolución de la alegría».

Alegría politica, entonces, surge como una página en Facebook y en Twitter que trabaja sobre ese doble sentido - la alegría como producto del humor pero también como leitmotiv de una cínica campaña política- y que vuelve a «cargar las tintas», con dicho adjetivo, sobre un concepto que podía percibirse frívolo (incluso «antipolítico») $)^{5}$ representado, metonímicamente, en los «globos» amarillos (relacionados con la apariencia, la superficialidad, por sobre el contenido) que adornaban la propuesta de Cambiemos, junto con otras consignas en la misma tónica, como «Sí se puede».

Si bien los temas abordados en Alegría son numerosos, nos interesa, como ya señalamos, focalizarnos en aquellos relativos al pasado dictatorial reciente. Varias medidas de la gestión macrista, a la par de declaraciones de sus funcionarios en la misma línea, intentaron cuestionar algunas verdades ya consensuadas en el relato sobre la memoria construido a lo largo de la posdictadura, lo cual generó controversia y puso en tela de juicio a figuras y agrupaciones vinculadas a la política de DD. HH. llevada adelante durante el período kirchnerista. Alegría, por supuesto, se hizo eco de tales operaciones simbólicas desde el gobierno de Mauricio Macri.

Nuestra hipótesis sostiene que estas piezas de humor no solamente contestan a un discurso reaccionario, sino que también se atreven a deconstruir ciertas mitificaciones sobre el pasado reciente o a reforzar (de modo no aurático, ya sea mediante la irreverencia o la provocación) algunas creencias fundadas.

Véase El Cronista. «La agencia Télam distribuye ahora historietas kirchneristas», en El Cronista, 15 de diciembre de 2011. Disponible en: https://www.cronista.com/informaciongral/La-agencia-Telam-distribuye-ahora-historietas-kirchneristas-20111215-0056.html. Algunos años más tarde la seguiría el festival Comicópolis, surgido como un proyecto de la agrupación Viñetas Serias junto con Andrés Accorsi en el marco de Tecnópolis. Tras la asunción macrista, el Estado dejó de financiar este festival, que se sostuvo (con financiamiento privado y mudándose al Predio Ferial de la Rural) hasta 2018.

${ }^{4}$ Véanse Sasturain, J. «La nueva magia desaparecedora», en Página/12, 4 de abril de 2016. Disponible en: https:/www.pagina12.com.ar/diario/contratapa/13-296130-2016-04-04.html; у Bоroвio, F. «Tras el cierre del suplemento de historieta argentina de Télam, el portal Recursos Culturales pondrá online todos sus contenidos», en Recursos culturales, abril de 2016. Disponible en: https:// www.recursosculturales.com/cierre-suplemento-historieta-argentina-telam/

5 Véase Hildebrandt, J. «Alegría: Dancin’ in the Macrisis», en Comiqueando Online, 7 de noviembre de 2018. Disponible en: https:/www.comiqueando.com.ar/notas/alegria-dancin-in-the-macrisis/ 


\section{Sobre el humor como dispositivo revulsivo y las formas herejes de construir memorias}

La relación desigual con el poder es un elemento basal en el humor como práctica social, cultural y, claro, política; en particular en este tipo de piezas que apelan a la sátira, a la burla, a una referencialidad hereje. Andrade define al humor gráfico y político como «instrumentos capaces de desafiar y revertir la monumentalidad de figuras y personajes asociados al poder y a la cultura hegemónica», y agrega que tal operación desacralizadora «suele ser un acto de subversión, de contracultura». ${ }^{6}$ Esta postura nos remite a dos teóricos imprescindibles en nuestro abordaje, Bajtin y Burke, quienes han revisado justamente esta capacidad disruptiva del humor desde las narrativas populares. ${ }^{7}$ En tal sentido, hay dos elementos que nos parece importante destacar en estos autores: por un lado, el humor como una forma de participación de la «gente común» en el debate político; y, por otro, la legitimación de estas piezas como testimonios o documentos históricos. ${ }^{8}$

En este artículo, nos referimos tanto a la noción de memoria histórica (como la entendemos las sociedades que hemos atravesado procesos dictatoriales, genocidios y violaciones a los DD. HH. por parte de los Estados o de sectores de dichas sociedades) cuanto a las memorias colectivas:

En el plano social, las luchas por la memoria son siempre luchas por la identidad, ya de un grupo, ya individual, que debido a nuestra condición de ser-en-el-mundo y con-otros, toman también el carácter de lucha por el reconocimiento y contra la exclusión. En este marco me interesa pensar el rol de las artes en los procesos de memoria, ¿qué podemos esperar de una novela, de una película, de un collage sobre, por ejemplo, la violencia de los años 70 en la Argentina? O, en términos más generales, ¿qué nos pueden enseñar las artes sobre nuestro pasado, sobre nosotros mismos?

Dialogando con las tradiciones sobre memoria colectiva de Halbwachs y Ricoeur, Boido apunta sobre el asunto de nuestro interés: ¿qué posibilidades presentan las narrativas visuales, bien en la construcción de memorias colectivas, bien en la... cons-

\footnotetext{
${ }^{6}$ Andrade, P. «Presentación», en Montealegre, J. et al. Un país de tontos graves. Humor gráfico y politica en Chile. Santiago de Chile, DIBAM/Museo Histórico Nacional, 2017, p. 9.

7 Bajtin, M. Estética de la creación verbal. México, Siglo Veintiuno, 1999; Bur Ke, P. Visto y no visto. El uso de la imagen como documento histórico. Barcelona, Crítica, 2005.

8 Burke, P. Op. cit. Las recopilaciones anuales en libro incorporan cronologías infográficas y un resumen mes a mes de los hechos más relevantes de la realidad política argentina de cada momento, como un intento de mantener actualizado el contexto de producción de los cuadros de humor y facilitar así su recepción humorística.

9 Boido, M. «Las artes y la construcción de la memoria», en Semilla Durán, M., Rosler, M. y Hernández, S. (ed.) Memoria de la ficción, ficción de la memoria: entre el ritual y la crítica. Columbus, The Ohio State University, 2018, p. 221.
} 
trucción de determinado(s) relato(s) sobre el pasado reciente? Desde una perspectiva general, tal preocupación ha sido abordada por autores como White ${ }^{10} \mathrm{o}$ Rosenstone, ${ }^{11}$ abocados a la literatura o al cine dentro del género histórico. Sin embargo, en este trabajo, el objeto son los cómics o, específicamente, el humor gráfico. Volvamos a los aspectos gráficos, más propios de nuestro lenguaje, entonces.

Hillary Chute, refiriéndose al dibujo como medium documental, nos dice que este, a través de la manifestación de marcas o trazos, no solo nos ofrece su propia forma de espesura temporal (thicket of time), sino que también «nos fuerza a detenernos y a entrar en su tiempo», parafraseando a Berger. ${ }^{12}$ Asimismo, según señala Levín en relación con las piezas de humor gráfico del período 1973-1983 publicadas en el diario Clarín, si bien pueden considerarse como «efímeras miniaturas» que, aisladas, quizás resulten irrelevantes, «conforman un objeto de enorme potencialidad simbólica y heurística, [...] al mismo tiempo productoras y espejo de los procesos colectivos de significación de esa experiencia histórica de los que constituyen, por otra parte, su huella». ${ }^{13}$

Para complementar lo anterior, cabe remitirnos a Montealegre quien, en relación a Pierre Nora y al concepto lugar de memoria, define los dibujos como artefactos culturales y formas de expresión de lo emotivo. ${ }^{14}$ Este último aspecto resulta central para entender el motor del humor de Alegría. No solamente se trataría de un posicionamiento político de los autores, sino también de un sentir: un revivir el trauma de pasadas crisis, la experiencia de violencias materiales o simbólicas de nuestra historia reciente que han marcado las prácticas y la memoria sensible de nuestra comunidad.

Como señalamos anteriormente, nos interesa revisar si estos «chistes» funcionan como discursos revulsivos, críticos o desmitificadores, pero también debemos determinar los alcances de tal operación. Es decir, entender cuáles son sus límites o tabúes, en especial al tratarse de un tema tan sensible como el pasado dictatorial y sus repercusiones. Al respecto, sospechamos que lo emotivo emerge como un elemento determinante, quizá por sobre el posicionamiento o la militancia política de los autores.

Burkart, comparando los discursos gráficos de la revista Humor respecto de Satiricón, refiere a una «domesticación de la irreverencia» como marca del terrorismo de Es-

${ }^{10}$ White, H. Metahistoria. La imaginación histórica en la europa del siglo XIX. México, Fondo de Cultura Económica, 1992.

11 Rosenstone, R. Cine y visualidad. Historización de la imagen contemporánea. Santiago de Chile, Finis Terrae, 2013.

12 Chute, H. Disaster Drawn. Visual Witness, Comics, and Documentary Form. Cambridge, Harvard University Press, 2016, p. 21.

13 Levín, F. Humor político en tiempos de represión (Clarín, 1973-1983). Buenos Aires, Siglo XXI, 2013, p. 17.

14 Montealegre, J. Derecho a Fuga. Una extraña felicidad compartida. Santiago de Chile, Asterión, 2018. 
tado. ${ }^{15}$ Nos interesa rescatar tal idea para revisar los procesos discursivos de Alegría desde sus inicios en las redes sociales hasta la publicación de su tercer anuario, ${ }^{16}$ entendiendo que tal domesticación, si así se confirmara, puede darse por factores que, obviamente, tendrían que ver con la coyuntura y el estado del campo de la historieta actual.

Al humor como salida o recurso de supervivencia ante una situación opresiva o traumática también se refiere Montealegre. ${ }^{17}$ Es necesario destacar nuestra propia postura respecto de la presente crisis argentina como una conmoción económica, social y política que se traduce en un trauma colectivo: por lo mismo, si bien el escenario al que remite Montealegre es diferente en varios aspectos (la cotidianeidad de los prisioneros políticos durante la dictadura chilena), entendemos que algunas operaciones discursivas del humor en contextos hostiles pueden servir para comprender lo que sucede en el caso de Alegría. El investigador chileno cita a Chaya Ostrower ${ }^{18}$ (y su texto titulado «Sin humor nos hubiésemos suicidado») respecto del humor negro entre los prisioneros de Auschwitz; asimismo, relata algunos casos de prisioneros políticos en Chile y de su propia experiencia en Chacabuco. ${ }^{19}$ En todos estos casos, se destaca la cohesión social ejercida mediante el humor como juego compartido, en una especie de complicidad entre desgraciados «para desdramatizar el duelo y elevar el ánimo en el enfrentamiento y superación de la adversidad». ${ }^{20}$

\section{Una embestida satírica contra las políticas del olvido}

Hemos seleccionado y categorizado las piezas de humor en base a ciertos lugares comunes a los cuales estas apelan. Esos lugares comunes (tanto discursivos como icónicos) en la representación de la dictadura, al ser reconocibles - el Ford Falcon verde utilizado en operativos clandestinos, el pañuelo blanco de Madres y Abuelas de Plaza de Mayo, la picana eléctrica, las consignas como «Nunca más», entre otros- permiten que el humor funcione con una rápida identificación, en un terreno conocido que escapa a la mera actualidad; destacan, no obstante, los cruces entre dictadura y

15 Burkart, M. De Satiricón a Humor. Risa, cultura y política en los años setenta. Buenos Aires, Miño y Dávila, 2017, p. 17.

${ }^{16}$ Los tres libros que seleccionan y recopilan material publicado en las redes y producen nuevo fueron editados con los títulos Alegría. Primer anuario, Alegría. Segundo anuario y Alegría. Tercer anuario por La Maroma Ediciones en Buenos Aires en los años 2017, 2018 y 2019. En las tapas (obra del Polaco Scalerandi) aparecen, respectivamente, Mauricio Macri, Patricia Bullrich y Elisa Carrió.

17 Montealegre, J. Op. cit.

18 Ibid., p. 313.

19 El campo de prisioneros de Chacabuco fue creado en 1973, tras el golpe de Estado a Salvador Allende. Funcionó hasta 1975 y por allí pasaron más de mil presos políticos.

20 Montealegre, J. Op. cit., p. 313. 
macrismo que establecen una estrategia discursiva de lectura sobre el presente como réplica del pasado. Para definir estos tópicos se tuvieron en cuenta «tanto las recurrencias y las insistencias como las excepciones, los ejemplos únicos que rompen las cadenas de sentido». ${ }^{21}$

Se puede, entonces, categorizar a estos chistes según la referencia al ya mencionado Ford Falcon verde; ${ }^{22}$ a las Madres y Abuelas o al pañuelo blanco (entre los que podemos desagregar aquellos que utilizan el símbolo del pañuelo de modo autónomo y aquellos que se refieren a Hebe de Bonafini, de modo más personalizado); al dictador Jorge R. Videla (utilizado como sinécdoque de los genocidas); al retiro de los retratos del mismo Videla y de Bignone por orden de Néstor Kirchner ${ }^{23}$ (como hecho-símbolo de un punto de inflexión en las políticas estatales sobre la memoria); a Santiago Maldonado ${ }^{24}$ (como manifestación de las prácticas represivas actuales en espejo con las prácticas de la dictadura); y al uso de las frases-consigna, entre las que se destacan «Nunca más», «Memoria, Verdad y Justicia», «Las urnas están bien guardadas», «(No) fueron 30.000», «Sí se puede»; «Los dinosaurios van a desaparecer» (24/3/2017, por Agite) $;^{25}$ y al nazismo (como analogía con el gobierno macrista) (19/5/2018, «Hitler, Videla, dos tipos macanudos», por Razz). Esas categorías se ven aplicadas en el cruce del campo semántico dictadura con situaciones actuales como la del fallo del llamado «2x1» ${ }^{26}$ o la desaparición del ya mencionado Maldonado.

${ }^{21}$ Levín, F. Op. cit., p. 26.

${ }^{22}$ E1 Ford Falcon, en especial de color verde, era el modelo de coche utilizado por los «grupos de tareas» para el secuestro de personas durante los años setenta.

${ }^{23}$ E1 24 de marzo de 2004, con motivo de un acto por el aniversario del golpe de Estado de 1976, el entonces reciente presidente Néstor Kirchner ordenó al titular del Ejército que retirara los cuadros de los dictadores Videla y Bignone que permanecían colgados en la galería del Colegio Militar. Ese hecho se convirtió en un símbolo sobre los cambios de políticas en DD. HH. que asumiría su gestión respecto de las anteriores.

${ }^{24}$ El 1 de agosto de 2017, en el marco de un corte de ruta por un reclamo territorial de la comunidad mapuche, Gendarmería Nacional llevó a cabo un operativo represivo que incluyó disparos de bala y la desaparición de Santiago Maldonado, un joven de 28 años. Tras setenta y siete días de intensa búsqueda, de fake newws, de extorsiones al juez y de espionaje a la familia del joven, su cuerpo fue encontrado en el río Chubut, con signos de ahogamiento. Si bien las sospechas apuntaban a los funcionarios de Gendarmería, tras una investigación cuestionada en la cual se destruyeron pruebas, el juez de la causa (Lleral) decidió cerrarla en un fallo polémico y sobreseer al único imputado, gendarme Echazú, el 29 de noviembre de 2018. E1 6 de septiembre de 2019 se reabrió la causa para cumplir con las medidas de prueba que no se habían realizado y se dejó sin efecto el sobreseimiento del gendarme.

${ }^{25}$ La canción «Los dinosaurios» aparece en el álbum Clics modernos (1983) de Charly García. En ella, el autor se refiere a las desapariciones y a los crímenes de la dictadura, estableciendo una analogía entre dinosaurios y genocidas. Esta canción y sus metáforas forman parte del imaginario social posdictatorial argentino.

${ }^{26}$ La ley 24.390 existió entre 1994 y 2001 en Argentina, con el fin de reducir la población carcelaria. Pasados los dos primeros años de prisión preventiva sin condena, cada día de detención se aplicaban 
E1 24 de marzo de 2019 desde las redes del colectivo se compartieron, en general, piezas de años anteriores. Entre las nuevas, se destaca la de Jericles, dividida en dos viñetas que representarían una de las "grietas» de la sociedad argentina: la parte superior muestra una «semana de la Memoria» (con una multitudinaria marcha con pancartas que exponen las consignas «30 mil desaparecidos», «Hijos y Abuelas», «Nunca más» y «Juicio y castigo»), mientras que en la viñeta inferior se observa la «semana de la desmemoria» (con otra marcha menos masiva en la que los manifestantes, a través de globos de diálogo individuales, plantean «Aquí no pasó nada», «Fue una guerra», «iAlgo habrán hecho!» y «Borrón y cuenta nueva»). Se muestran las dos realidades enfrentadas en lo que respecta a los relatos sobre el pasado reciente: uno corresponde a la búsqueda de justicia y de DD. HH.; el otro, a las llamadas «políticas del olvido», ${ }^{27}$ particularmente fuertes durante los años noventa y que se reactivaron durante la gestión macrista (basadas en una supuesta «reconciliación» social que, concretamente, busca la impunidad de los crímenes de la dictadura).

Dos cuadros, publicados el 24 de marzo de 2018, toman a Macri como blanco de sus críticas: el de Roy y Nani muestra otra gran marcha — con pancartas que rezan «iSon 30.000!» y «Memoria, Verdad y Justicia»-, delante de la cual se ve a una Madre con el pañuelo blanco y, en el fondo, la Casa Rosada. Desde el interior una voz, que imita la característica dicción de Macri, le grita a su esposa (Juliana Awada): «Juli, ¿¿่hoy esh el día de losh deshapareshidos?? ¡¡Con rashón no me dejan aparesher!!». Aquí, como en otras piezas que veremos (Riskin, «Guerra sucia»; Otto, «Meme de Drake», FIG. 11), el uso un tanto socarrón (o descuidado) del verbo aparecer parece estar avalado o habilitado porque el enunciador es Macri, quien además se refiere al 24 de marzo con la errónea y simplista frase «Día de los desaparecidos» en lugar de utilizar la denominación oficial de «Día Nacional de la Memoria por la Verdad y la Justicia». De esa forma, se ve parcialmente mitigada la irreverencia de hacer un juego asociativo bastante infantil con la tristemente famosa palabra desaparecidos. En el cuadro de Max SQ (24/3/2018), el presidente Mauricio Macri está vestido con ropa deportiva (una vincha o diadema con el logotipo de Nike y una remera en la que se lee «I love 90's») en una cancha de pádel, deporte que tuvo su auge en los años noventa, durante el período más álgido de neoliberalismo del gobierno de Carlos Menem. Con un teléfono celular en la mano, se lee a su interlocutor: «Mauricio, están preguntando si hacemos acto oficial por el día de la memoria», a lo que el presidente responde: «Deciles que me olvidé». ${ }^{28}$ Este chiste propone un cruce de dos representaciones

como doble. A pesar de haber sido derogada, el 3 de mayo de 2017 la Corte Suprema de Justicia decidió que era aplicable en el caso de un detenido por crímenes de lesa humanidad, Luis Muiña, y redujo su pena. Ante el antecedente que podía representar para los casos de otros genocidas presos, el 10 de mayo se organizaron marchas masivas en todo el país reclamando por la no implementación del beneficio a represores.

${ }^{27}$ Vezetti, H. Sobre la violencia revolucionaria. Memorias y olvidos. Buenos Aires, Siglo XXI, 2009.

${ }^{28}$ Este chiste puede relacionarse con el intento de Macri de convertir (por decreto) en «feriado trasladable» el día 24 de marzo, Día Nacional de la Memoria por la Verdad y la Justicia (junto con el 2 


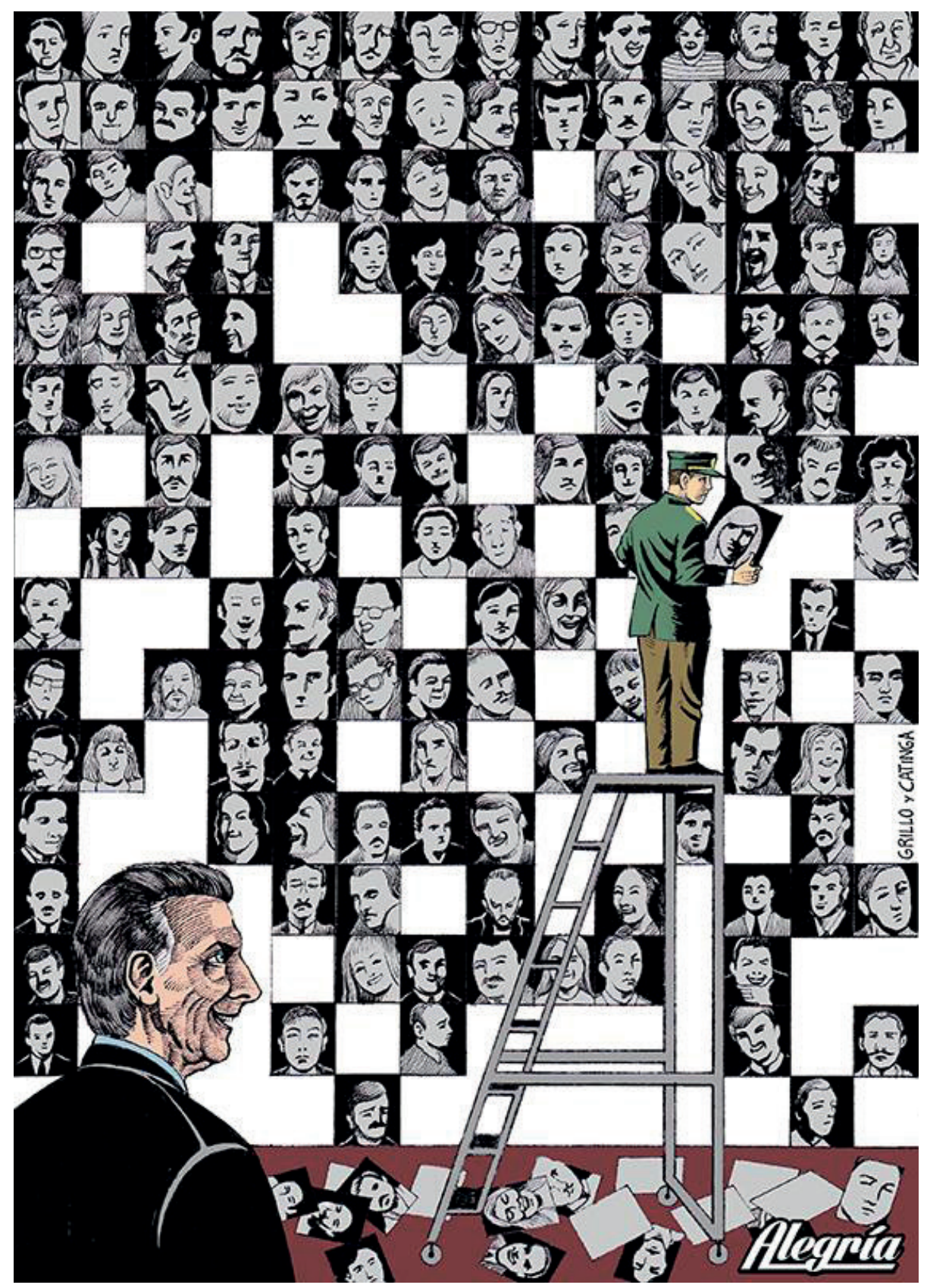

FIG. 1. Alegría política, 2018, Guillo y

Catinga.

de abril, Día del Veterano y de los Caídos en la Guerra de Malvinas, y el 20 de junio, Día del Paso a la Inmortalidad del General Manuel Belgrano, popularmente conocido como «día de la bandera»), que fue rechazado por los organismos de DD. HH. y debió ser rectificado. Véase Página/12. «Macri firmó la marcha atrás con el feriado del 24 de marzo», en Página/12, 1 de febrero de 2017. Disponible en: https:/www.pagina12.com.ar/17492-macri-firmo-la-marcha-atras-con-el-feriado-del-24-de-marzo. 
habituales de Macri en el imaginario popular: por un lado, su falta de predisposición al trabajo; por otro, su rechazo a las políticas de la memoria.

Otros artistas recurren a la figura de Mirtha Legrand ${ }^{29}$ transmutada en disimulado dinosaurio, hecho que (además de ser una chicana respecto de la edad de la diva) establece una clara analogía entre su pensamiento reaccionario y la figura con la que se identifica a los partidarios de derecha y militaristas en Argentina (Agite). Otros se refieren a la icónica escena de Néstor Kirchner ordenando descolgar el cuadro de

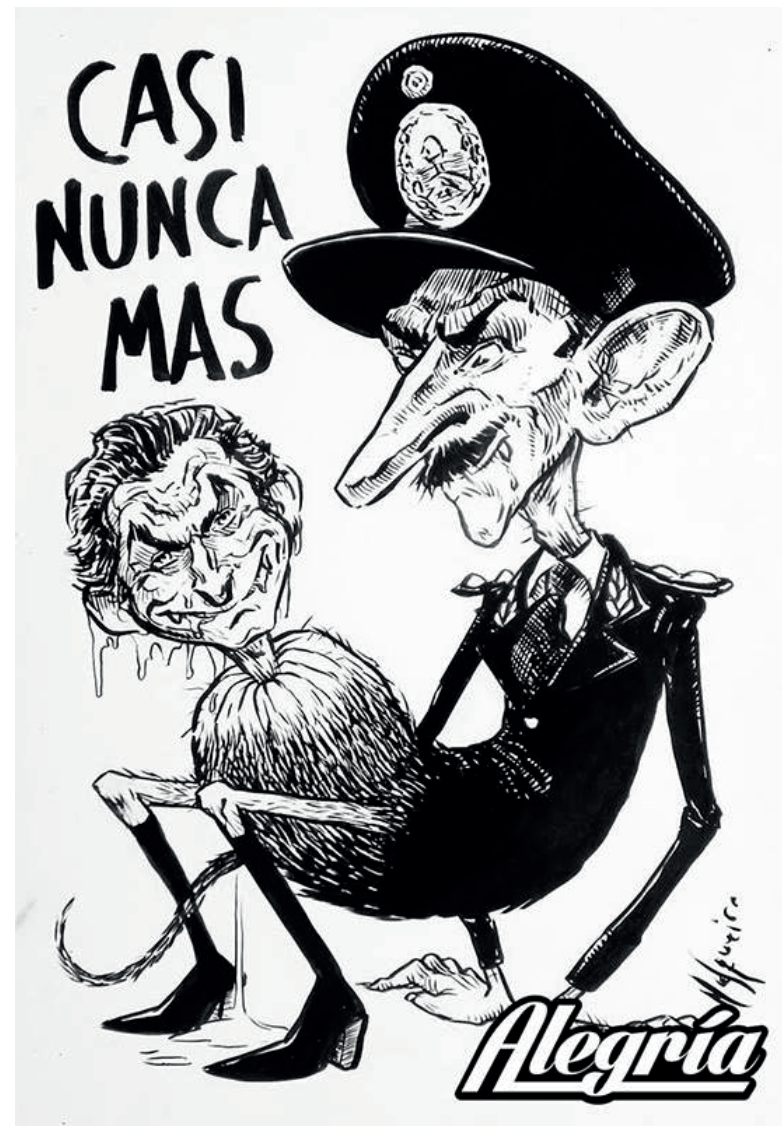

FIG. 2. Alegría politica, 2018, Mosqueira.

los genocidas de la ex Escuela de Mecánica de la Armada (Grillo y Catinga, FIG. 1), aunque la figura del expresidente es reemplazada por la de un Macri sonriente que, por el contrario, lo que hace descolgar a un militar son las fotos de los desaparecidos como desarmando un rompecabezas, lo cual alude al desguace de la políticas de DD. $\mathrm{HH}$. durante la gestión de Cambiemos. ${ }^{30}$ Hay autores que utilizan la polémica figura

${ }^{29}$ Longeva actriz y conductora de televisión, conocida por sus declaraciones reaccionarias.

${ }^{30} \mathrm{El}$ conjunto de fotografías hace referencia también a los recordatorios de desaparecidos como los publicados por el diario Página/12: https://www.pagina12.com.ar/secciones/recordatorios. 
de César Milani ${ }^{31}$ (Porcino) y otros que cruzan (casi fusionan, podríamos decir) la imagen de Macri con la del dictador Jorge R. Videla (Maléfico): acompañados por la leyenda "Casi Nunca Más», ambos personajes componen una especie de ser monstruoso en el que Macri actúa como el «aguijón» de Videla (FIG. 2). La mayoría de estas piezas podrían funcionar publicadas en cualquier 24 de marzo - como la mencionada de Jericles, quizás el mejor ejemplo-, pero algunas tienen marcas coyunturales (el presidente Macri o algún otro miembro de su gobierno) que se cruzan con figuras o situaciones más omnipresentes como Videla, las marchas del Día de la Memoria o las consignas, que ya son parte de la memoria cultural relacionada con ese día. ${ }^{32}$

Entre los trabajos referidos a las Madres y Abuelas de Plaza de Mayo encontramos dos subcategorías: los que apelan al símbolo del pañuelo blanco y los que utilizan la figura de la Madre/Abuela, entre los cuales hay un subgrupo destinado a Hebe de Bonafini, en particular. Sobre esta última, encontramos una variedad de representaciones más amplia que en los casos de otras figuras relacionadas con las agrupaciones de DD. HH. En parte, entendemos que se debe a su protagonismo mediático, a su fuerte personalidad «sin filtro» que cosecha amor de los sectores juveniles y críticas de los espacios más conservadores de la sociedad. Con esta «grieta» o tensión juegan las representaciones de los trabajos de Maléfico (FIG. 3) y de Sergio Langer (FIG. 4). La primera, publicada originalmente en agosto de 2016 (Primer anuario), es una clara referencia a la imagen icónica de Maradona en la final mundial contra Alemania Federal en México '86, muy presente en el imaginario popular como símbolo de habilidad para esquivar mediante gambetas a los oponentes: una traducción lúdica de la lucha social e, incluso, antimperialista. ${ }^{33}$ Se apela a lo emotivo, a la memoria sensible de los lectores o visitantes de las redes para establecer una comparación, una operación de espejo, entre la transformación «del Diego» y de Hebe (ya identificables popularmente solo por sus nombres de pila) desde sus respectivos orígenes en los sectores humildes y trabajadores hasta su conversión en referentes. Pero, sobre todo, en

${ }^{31}$ Jefe del Estado Mayor General del Ejército Argentino, entre 2013 y 2015. Fue procesado por varios casos de enriquecimiento ilícito, secuestro, tortura y asesinato mientras era oficial subalterno en el período dictatorial. De varias de estas causas ha sido absuelto; no obstante, su figura sigue siendo controversial e incluso, en algunos espacios políticos, repudiada.

32 Un chiste de Mantrul del 25 de marzo de 2017 juega con esa referencia: «25 de marzo. Día del Olvido». Un personaje le dice a otro: «Te acordás que ayer hubo como una marcha», a lo que el otro responde: «Sí... más o menos, había unas viejas en un escenario». La alusión irreverente a las Madres y Abuelas nuevamente se mitiga a partir del lugar de enunciación del que proviene: una persona «sin memoria» que se queda en la observación despectiva, superficial.

${ }^{33}$ El dibujo se hizo con motivo del intento de detención de Hebe por parte de la policía (4 de agosto de 2016). Dos años después, un comunicado de las Madres de Plaza de Mayo rememora el hecho y es acompañado por la ilustración de Maléfico, que interpreta así: «su rebeldía y coraje le permitieron gambetear el cerco policial. Miles de personas salieron a la calle para celebrar esa jugada maradoniana. Y para generar al equipo más invencible: el pueblo unido». Véase S.a. «Las Madres recordaron la "gambeta y jugada maradoniana" de Hebe de Bonafini para no ser detenida", en Secciones Bonaerenses, 5 de agosto de 2018. Disponible en: http://www.seccionesbonaerenses.com/nota. asp?n=unica\&id=27810\&id tiponota $=28$ 
su lugar de personajes incómodos o provocadores para ciertos sectores de la sociedad argentina, tanto aquellos grupos que han alentado un discurso de desprestigio hacia las políticas de DD. HH. a partir del ataque a Hebe como también, desde una lectura más amplia, quienes atacan a Maradona principalmente por manifestar su simpatía ideológica por el kirchnerismo - más allá de otras controversias personales de esta figura- La equiparación de ambos remite a la comparación entre sus atributos más característicos, que parece revisar una premisa del mito maradoniano: el pañuelo, como la pelota, «no se mancha». ${ }^{34}$ Una manifestación de ello son algunos de los comentarios de usuarios/lectores que suscitó el reposteo reciente de esta imagen:

- Federico Palacio: notaron cómo odian a Hebe por ser la más quilombera y con más aguante? pareciese que prefieren una figura menos «polémica» y más políticamente correcta..

- Diego Biber: E1 Diego y Hebe, 2 iconos [sic] de la Argentina, que representa parte de lo mejor del país... Pero que a veces habría que mantenerlos callados un ratito.

- Nicolas Nikolakis: Despues [sic] de todo lo que HIZO se puso a decir BOLUDECES.... IGUAL QUE EL DIEGOTE !!!

- Federico Perren: Hace referencia a que juega intacta. Que es la mejor de nosotros.

- Catriel Fernández: Con Norita [Cortiñas] es más creíble!!35

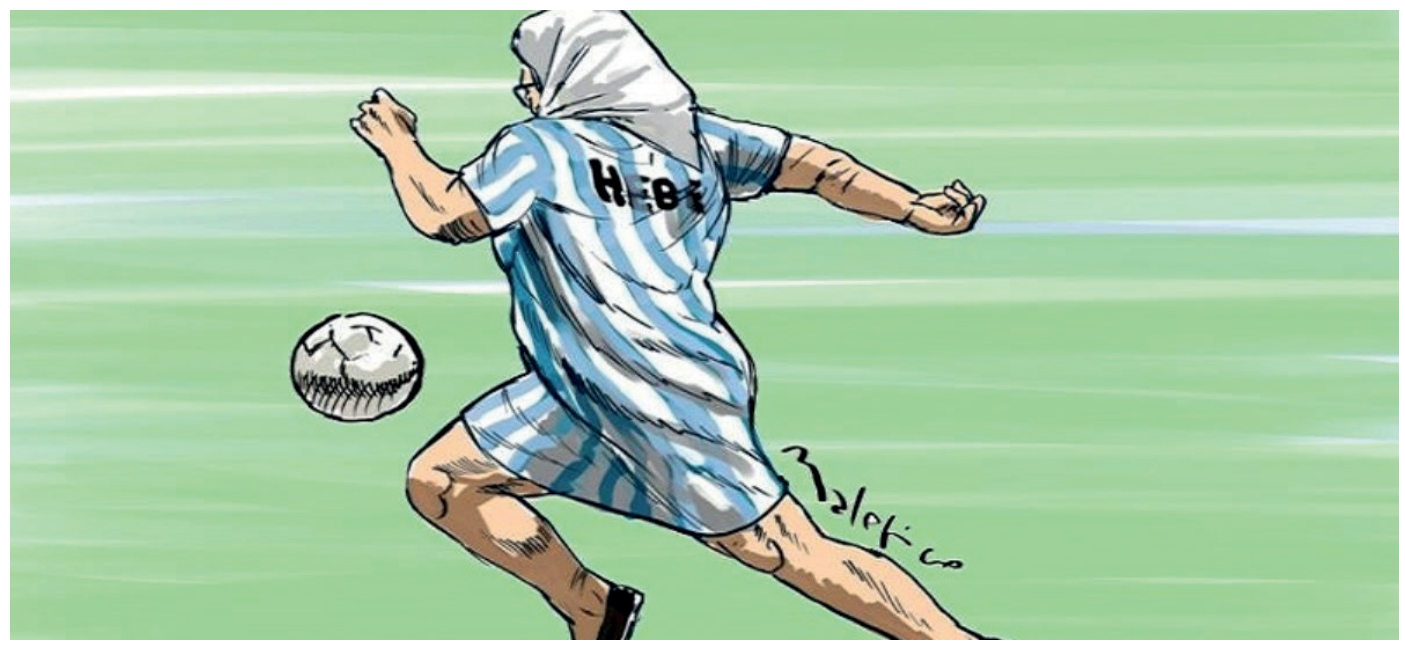

FIG. 3. Alegría política, 2018, Maléfico.

${ }^{34}$ Frase inmortalizada por Diego Maradona, parte del discurso que pronunciara en su partido-homenaje el 10 de noviembre de 2001 en la Bombonera: «El fútbol es el deporte más lindo y más sano del mundo. «De» eso no le quepa la menor duda a nadie. Porque se equivoque uno, no, no tiene que pagar el fútbol. Yo me equivoqué y pagué. Pero... [ovación] pero la pelota no, la pelota no se mancha [ovación aún más fuerte]». Disponible en: https://www.youtube.com/watch?v=Q8RvuFyDMog

35 Alegría (Facebook), 24 de marzo de 2019. Disponible en: https://www.facebook.com/alegriapolitica/photos/a.1749874575249751/2368088513428351/?type=3\&theater 


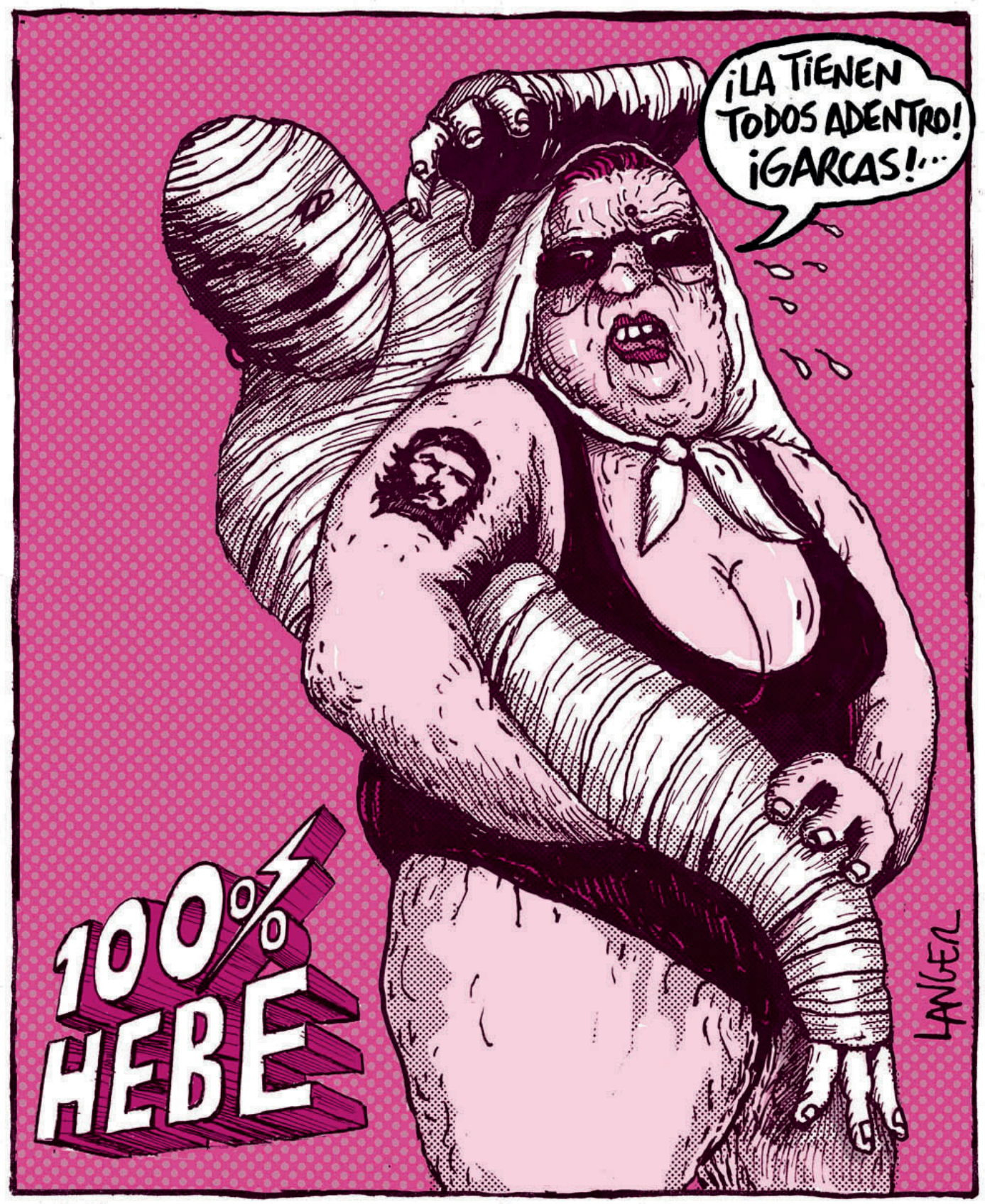

FIG. 4. Alegría política, 2018, Langer.

El trabajo de Langer, publicado también en el Primer anuario (agosto), entra en la categoría de irreverente, como suele suceder con las obras de este autor. Su estilo gráfico general se caracteriza por lo grotesco, con una línea expresiva y una síntesis caricaturesca que pone énfasis en los aspectos menos honorables del representado y que 
remite al estilo de Philippe Vuillemin. ${ }^{36}$ En este caso, además, lo desplaza a un plano inesperado: Hebe es representada como un personaje del programa televisivo de catch $100 \%$ lucha, llevando su pañuelo y sus característicos anteojos oscuros, a los que les suma un tatuaje del Che Guevara en el brazo derecho (igual al que tiene Maradona) y una malla enteriza como la que usaba Martín Karadagián, ídolo máximo de otro programa de lucha libre, Titanes en el ring, con quien se la parangona. La podemos ver peleando con el personaje de La Momia (de Titanes...), que aquí parece funciona como símbolo de «lo retrógrado», ya que la ataca por la espalda. Aunque hace sudar a Hebe y amenaza su cabeza con la mano izquierda, la Madre parece tener el dominio de la situación, al atenazar el brazo derecho de La Momia. «100 \% Hebe», reza el chiste, estableciendo como sinónimos plenos, por sustitución en la misma posición del sintagma, los términos «Hebe» $\mathrm{y}$ «lucha». ${ }^{37}$

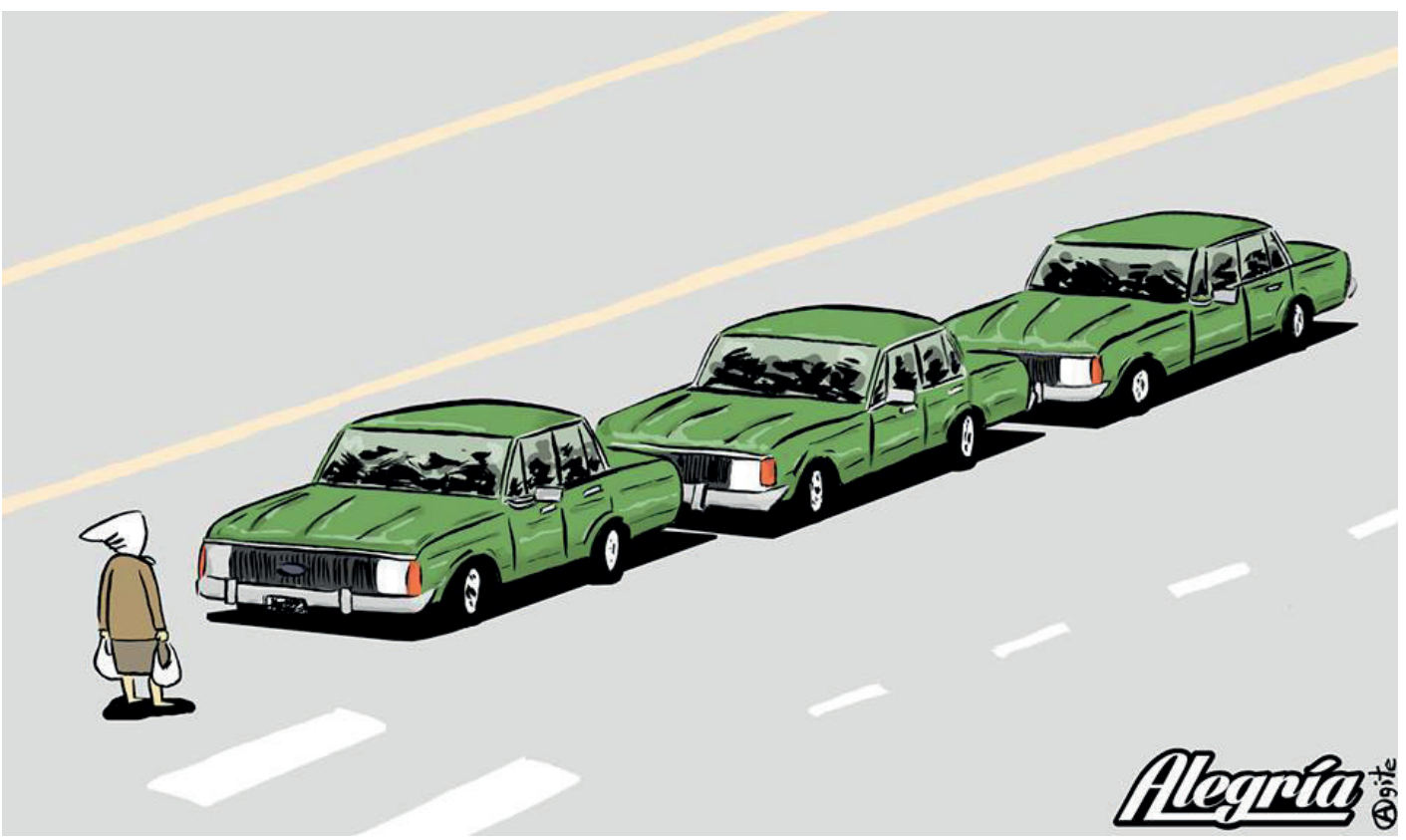

FIG. 5. Alegría politica, 2017, Agite.

En este grupo de referencias a Madres y Abuelas también encontramos trabajos como el de Agite (FIG. 5), publicado con motivo del 24 de marzo de 2017. En él, se alude a un símbolo histórico mundial de la resistencia pacífica: el «hombre del tanque» de la masacre de la Plaza Tiananmen de Pekín, en 1989. Ese personaje aún anónimo (que, se supone, fue una de las miles de víctimas de aquellas sangrientas jornadas de

36 Sobre el grotesco en Langer, véanse también Martignone, H. y Prunes, M. Historietas a diario. Las tiras cómicas argentinas de Mafalda a nuestros días. Buenos Aires, Libraria, 2008, pp. 106-109.

37 Aquí Langer «recicla» una ilustración realizada en 2014 para la revista Barcelona, dándole un plus interpretativo al incorporar el texto « $100 \%$ Hebe». 
junio) supo pararse frente de los tanques enviados por el gobierno chino a reprimir la protesta estudiantil: en la imagen reinterpretada, es reemplazado por una Madre; los tanques, por unos coches Ford Falcon verdes.

Otros casos dentro de esta línea apelan a un imaginario más directo, de lo cotidiano. Un ejemplo es el trabajo de López y Agite del 10 de mayo de 2017. Este cuadro se sitúa en el contexto del fallo de la Corte Suprema (parte fundamental del tercer componente de la tríada «Memoria, Verdad y Justicia») que permitía aplicar el beneficio del $2 \mathrm{x} 1$ a las penas de prisión en delitos de lesa humanidad (3/5/2017), como hemos explicado anteriormente. ${ }^{38}$ Una Madre o Abuela ocupa el rol de maestra (quizás en referencia a Estela de Carlotto, quien ejerció la docencia en el nivel primario) en un espacio áulico, mientras que un alumno está de «plantón» en el rincón por no saber la respuesta correcta (la emblemática frase «Nunca más», escrita en el pizarrón). Pese a estar de espaldas, se puede identificar al alumno «ignorante» con Macri, pues lleva puesta la banda presidencial con el diseño del pabellón argentino (que, irónicamente, también es la banda típica de los alumnos «abanderados»). La pregunta que la docente realiza - que parece tener un tono «amenazante» o admonitorio- mirando de frente es una pregunta habitual en una clase: «¿A alguien más no le quedó claro?». Pero aquí, estaría dirigida a los lectores, de forma más bien retórica: esto se refuerza por el hecho de que no se muestran bancos con alumnos en el aula, de modo que no se interpela a los hipotéticos estudiantes sino a la sociedad en su conjunto, señalando que quizás debe plantearse tal interrogante.

También «escolar» (pedagógica) es la escena elegida por Pipi Spósito (3/5/2017) en la que un niño (con cara de compungido) resuelve la multiplicación «2x1» en el pizarrón, escribiendo «un genocida suelto» (FIG. 7). Una voz que proviene de afuera del cuadro (suponemos que la maestra o el maestro, o por qué no, la sociedad) le responde que tiene «Un 0 en matemáticas... Y 10 en derechos humanos!», por lo que

38 Pertot, W. «Un rechazo que se convirtió en inmensa multitud», en Página/12, 11 de mayo de 2017. Disponible en: https://www.pagina12.com.ar/36972-un-rechazo-que-se-convirtio-en-inmensa-multitud. Además, el Congreso sancionó casi de inmediato (en el contexto de la fuerte movilización de la sociedad) una ley que impedía la aplicación del cómputo del 2x1 a casos de lesa humanidad; véase YвARRA, G. «El senado votó por unanimidad y es ley el límite al "dos por uno"», en La Nación, 11 de mayo de 2017. Disponible en: https:/www.lanacion.com.ar/politica/el-senado-voto-por-unanimidad-y-es-ley-el-limite-al-dos-por-uno-nid2022574. El 14/6/2017, Cape (FIG. 6.) realiza un cuadro en el que muestra a un militar anciano en la acción de arriar una bandera con la leyenda «FF. AA.» en rojo (y manchada de sangre, como sus manos), mientras derrama una significativa lágrima. Otros chistes muestran el cambio de actitud de los funcionarios del gobierno ante el repudio social. En el de Razz (11/5/2017), el secretario de DD. HH. (Claudio Avruj) antes de la marcha dice que respeta el fallo, mientras que después se lo ve encolerizado y gritando «iNo al fallo!» $y$ «justicia!», transformado cual Hulk (llevando incluso el pañuelo blanco), cuando la misma mano que lo sostenía (la sociedad) ahora lo aprieta un poco. En el de Giraldez y Podeti (10/5/2017), una mujer (María Eugenia Vidal) dice: «Che, ojo que a mí esto del 2x1 me parece re mal, eh», mientras lee un papel que se nos revela como «Guión de Durán Barba» (Macri y Avruj se pliegan a esa opinión, así como los tres jueces de la Corte Suprema que firmaron el fallo). 


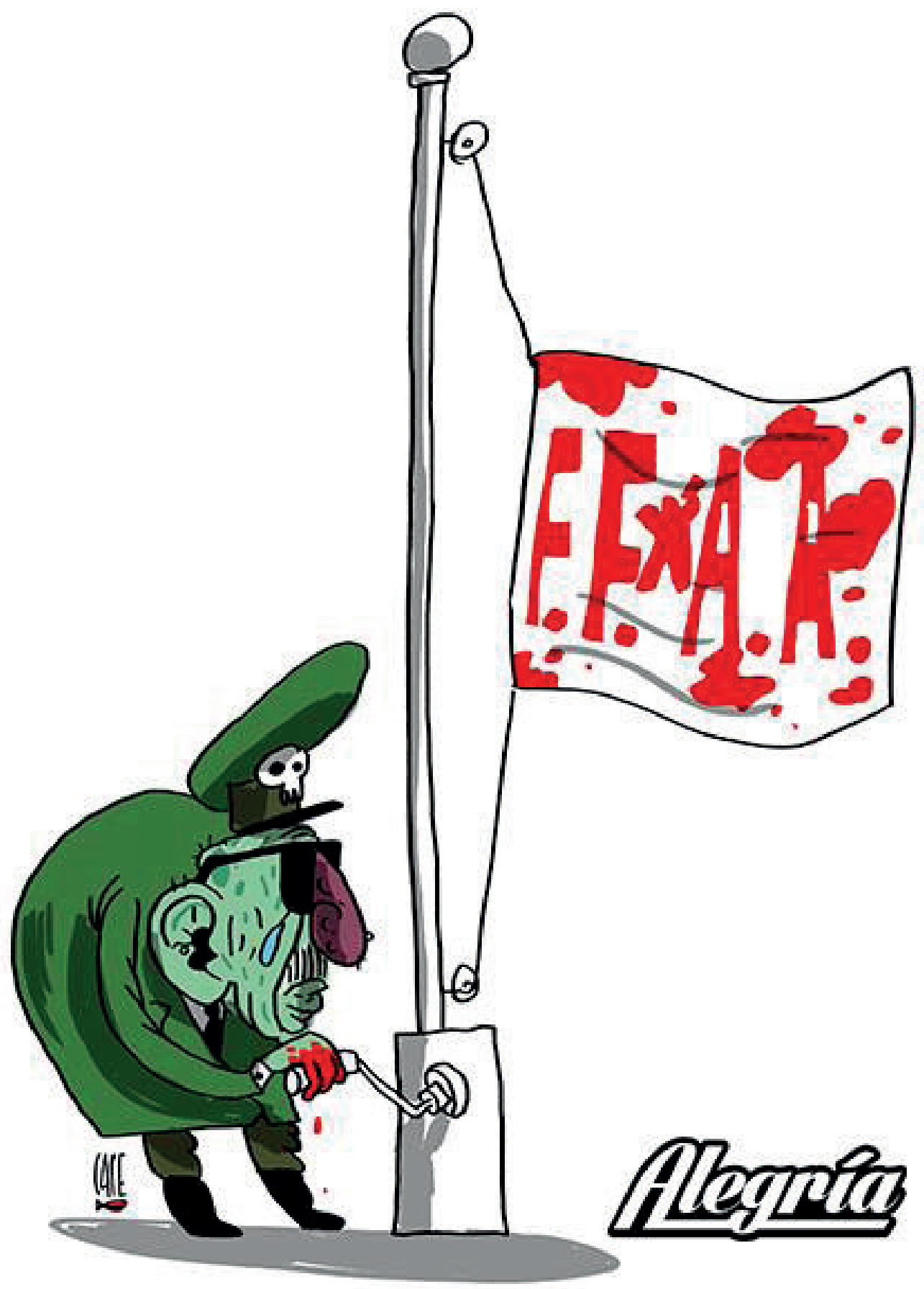

FIG. 6. Alegría politica, 2017, Cape. 
no terminará en penitencia como el «alumno-Macri» del chiste de López y Agite. Otto y Mantrul, por su parte, también desplazan hacia una situación cotidiana el fallo del $2 \times 1$ (3/5/2017). Un anciano con traje a rayas de presidiario (significativamente, el preso número 1976) y gorra militar está frente a la caja - debajo de esta un cartel anuncia: «2x1 Hijos de puta»- de un local de comidas que podría ser un McDonald's. Sin embargo, en el fondo se lee «Corte Suprem[a]» y la balanza de la justicia aparece dibujada dos veces, al tiempo que se ve un pilón de hojas que remite al cuestionado fallo. La cajera es una mujer que encarna la clásica representación de la Justicia. La venda no cubre el ojo izquierdo, indicando que ve con bastante claridad lo que está ocurriendo y, con una entusiasta sonrisa, le of rece al militar una promoción: «Por 50 centavos más, reducción de condena... Y aros de cebolla!». La Justicia se muestra como un lugar que ofrece a los militares un servicio veloz, como los locales de comidas rápidas, a cambio de un pago muy módico, por no decir ridículo, para los índices inflacionarios del momento. A la izquierda, como desde el margen, un niño con la camiseta de la selección argentina (representando a la sociedad) asiste a esta escena con expresión entre triste y consternada, sin poder reaccionar activamente, empequeñecido como un personaje secundario (el chiste se publicó el día del fallo).

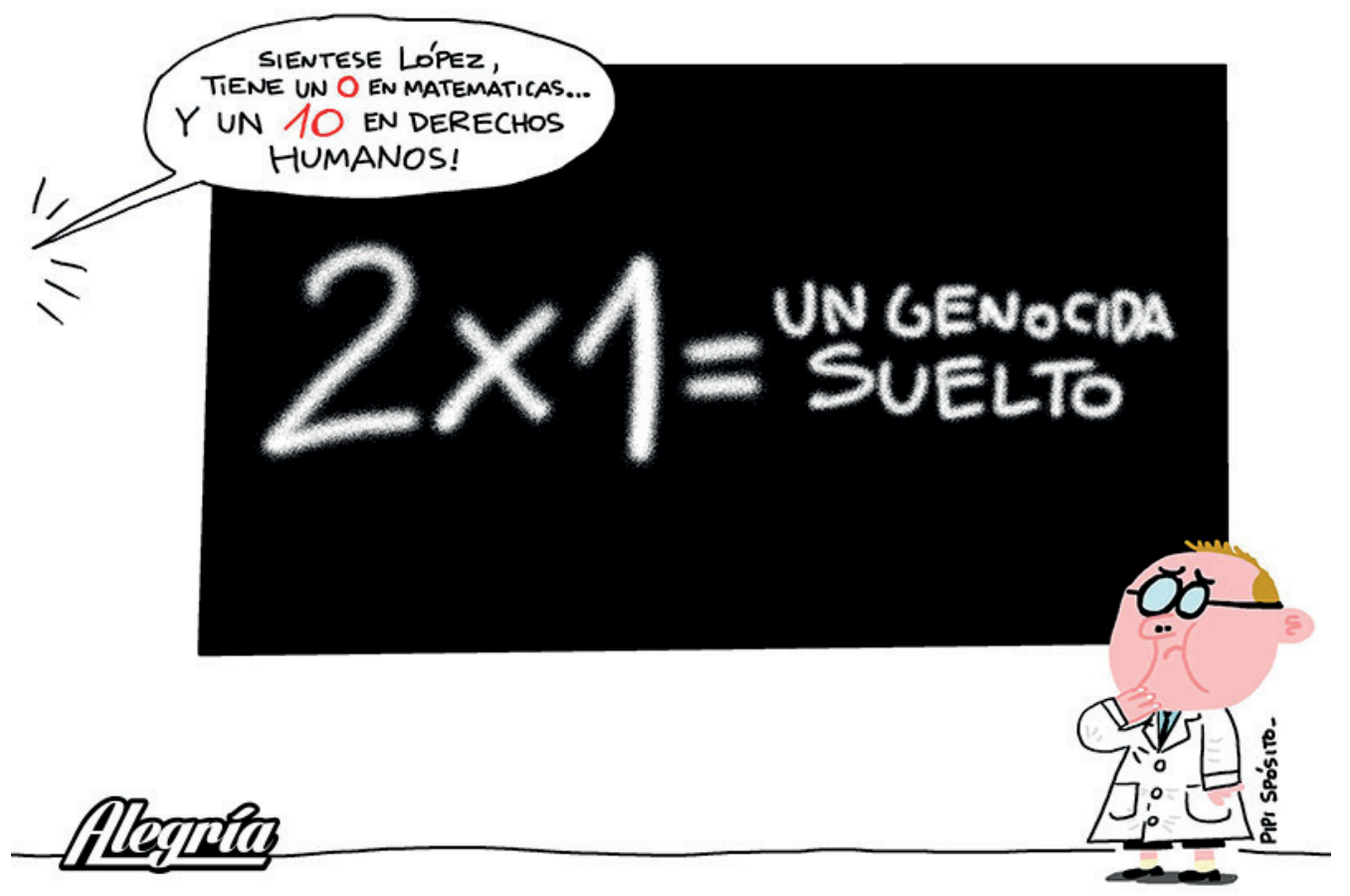

FIG. 7. Alegría politica,2017, Pipi Spósito.

Varios cuadros más se refieren a la relación de la Justicia con los militares, como el de Kripto «El sol del 2x1 viene asomando» (10/5/2017), en el que se ve a un hombre peludo (cuya piel tiene un color excrementicio) parado dentro de un inodoro y mi- 
rando hacia el exterior por una pequeña ventana con barrotes de una prisión (lo único que se aprecia del afuera es un omnipresente color amarillo, color identificado con el macrismo). ${ }^{39} \mathrm{El}$ título remite a una canción patriótica referida al 25 de mayo de 1810, por lo que se establece una asociación con ciertas ideas un tanto rancias acerca de militarismo y patriotismo. Además, el hecho de que el preso esté parado en el inodoro recuerda a la muerte de Videla — sentado en el inodoro de su celda, mientras purgaba su pena $-{ }^{40}$ y funciona como advertencia de que eso podría no ocurrir con quienes cumplen actualmente su condena (este militar está «de pie», expectante). El chiste de Maxi! (12/5/2017), por otra parte, advierte: «Ojo: con el 2x1 los represores vuelven a la calle»; un transeúnte se queja de haber sentido «electricidad estática» en el brazo y otro hombre, que va en dirección contraria - con sonrisa perversa, anteojos negros y sobre todo-, admite: «iQué electricidad estática ni ocho cuartos! Fue picana», refiriéndose al frecuente método de tortura aplicado en la dictadura por las fuerzas de seguridad. Con este fallo, se advierte, las calles volverán a ser inseguras para el pueblo, como durante el terrorismo de Estado.

La Iglesia tampoco queda fuera de la crítica de Alegría. Un cuadro de Kripto (4/5/2017) muestra una larga fila de militares esperando su turno en un confesionario donde los aguarda un cura, mientras un cartel (de color amarillo) anuncia «2x1». Maléfico (8/5/2017) alerta sobre la hipocresía de la Iglesia a través de la figura de un cura que afirma: «... Con total sinceridad, la Iglesia llama a los argentinos a la reconciliación...». Frente a él, los representantes de la sociedad (un hombre, una Madre o Abuela y un militar) reaccionan a sus palabras: el primero, con un gesto neutro en el rostro; la segunda, con una notoria mueca de enojo; el último, con una sonrisa. Esa sonrisa parece suponer el conocimiento de aquello que se revela en el dibujo del sacerdote: viste pantalones «verde militar», que quedan ocultos por el altar para quienes están del otro lado y contrastan con la «total sinceridad» que alega en su frase.

La idea de reconciliación también es visitada por Langer (9/5/2017) a través del encuentro de un militar, de amplia sonrisa, que tiende su mano a un hombre al que le faltan al menos un brazo y una pierna (utiliza una muleta) y le dice: «iBasta de revolver el pasado, es hora de que los argentinos nos demos las manos y dejemos cicatrizar las viejas heridas!». El cinismo está, además de en la mención de estrecharse las manos (que al otro parecen faltarle), en utilizar metafóricamente la palabra «cicatrizar», ya que al hombre (un civil, parado en un charco de sangre) todavía le sangran las múltiples heridas que le producen las armas blancas que tiene clavadas en la espalda $-\mathrm{y}$ algunos agujeros que podrían ser de bala - El hecho de que todas esas heridas

39 S.a. «Todo amarillo: el PRO y la mezcla entre propaganda y comunicación pública», en Télam, 16 de marzo de 2015. Disponible en: https://www.telam.com.ar/notas/201503/98240-campana-pro-publicidad-comunicacion-institucional-amarillo.html

40 S.a. «Difunden que a Videla lo hallaron muerto en el inodoro de su celda», en Perfil, 18 de mayo de 2013. Disponible en: https://www.perfil.com/noticias/politica/difunden-que-a-videla-lo-hallaronmuerto-en-el-inodoro-de-su-celda-20130518-0059.phtml 
abiertas estén en la parte trasera del cuerpo habla de un ataque a traición por parte del militar (o de los militares), quizás una referencia a la noción de «guerra sucia» (ver más adelante el análisis del cuadro de Riskin). Este cruce se hace patente también en un cuadro minimalista de Cape (4/5/2017, FIG. 8), que une un gorro militar con el símbolo de la balanza para formar los ojos, la nariz y el bigote: la justicia como la cara visible (pero algo disimulada) de las fuerzas armadas. El estridente fondo amarillo alude a la vez a la gestión macrista, garante o condición de posibilidad para que algo así suceda. ${ }^{41}$

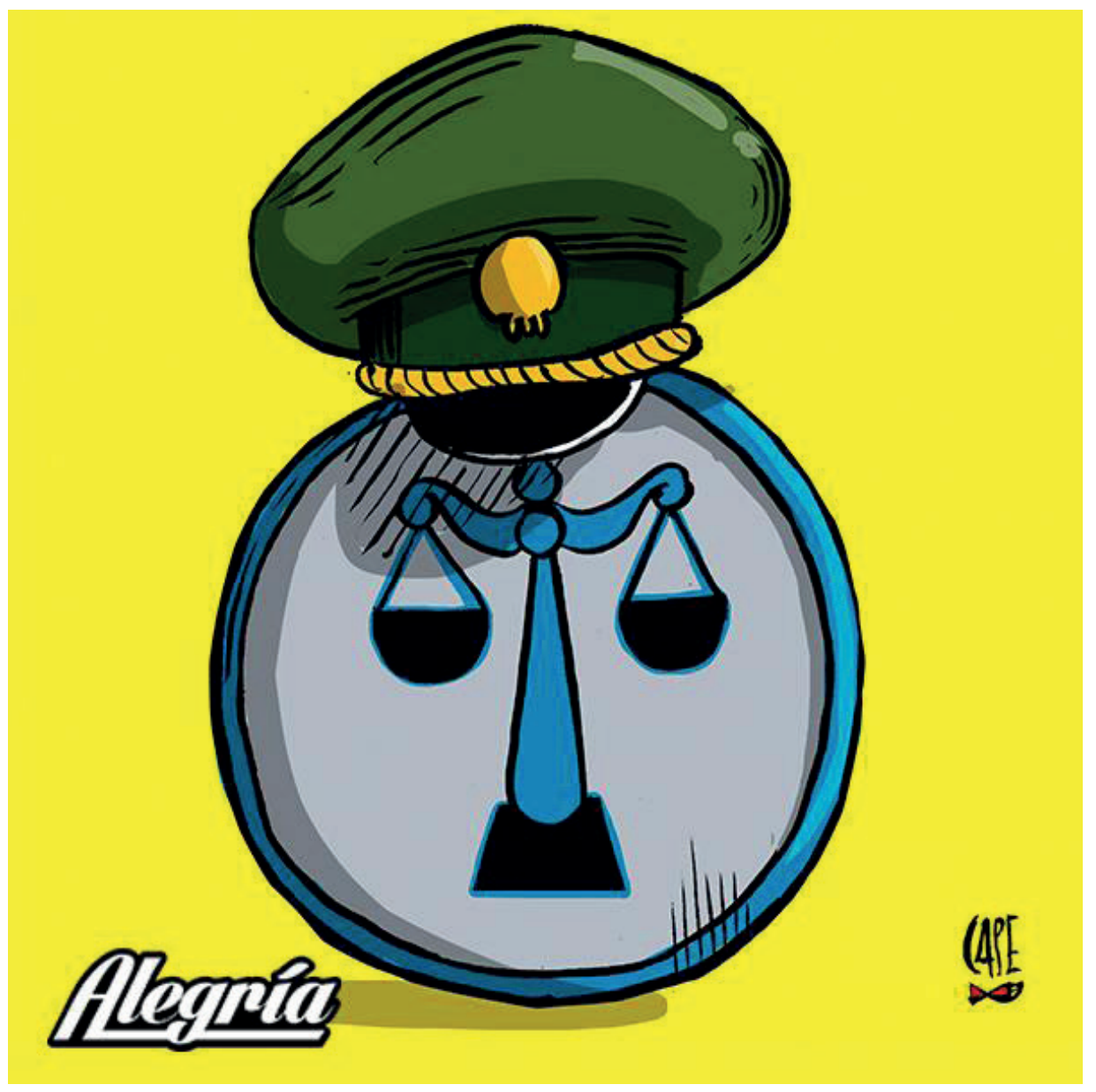

FIG. 8. Alegría política, 2017, Cape.

${ }^{41}$ Así puede apreciarse también en otras dos piezas. En un panel de Emiliano Tapia (8/5/2017), un militar demoníaco parado sobre un piso «alfombrado de muertos» (la frase está inspirada en Rodolfo Walsh) sostiene un globo amarillo que dice «2x1». En uno de Cape (8/5/2017), el autor inventa una señalización vial en la que se simboliza a un militar anciano en silla de ruedas, atravesando un senda peatonal, indicación o aviso a la sociedad de que ahora los militares tienen "prioridad». El fondo del cartel es amarillo y el borde inferior izquierdo se encuentra deteriorado, indicio del «descuido» o de la desidia del Estado respecto de esta polémica decisión, que parece avalar a partir de la colocación del cartel. 
Sin embargo, el ejemplo irreverente por antonomasia quizás sea la pieza gráfica de Otto y Lietti (11/5/2017, FIG. 9), referida también al episodio del 2x1. En la imagen, cinco cuerpos (cinco son los jueces de la Corte Suprema) caen desde un avión militar hacia una masa de agua, en alusión a los «vuelos de la muerte» que realizaban los militares durante la dictadura para deshacerse de detenidos desaparecidos, arrojándolos al Río de la Plata. ${ }^{42}$ Los autores, entonces, plantean aplicar ese mismo accionar como castigo a los cinco jueces del máximo tribunal (aunque solo tres firmaron el fallo con la aplicación de la reducción de pena y dos lo hicieron en disidencia). ${ }^{43}$ Los jueces no son reconocibles por sus rasgos, sino por su atuendo y, sobre todo, por las clásicas pelucas que solían usar estos magistrados antiguamente, lo cual enfatiza el carácter retrógrado del fallo. Otro detalle interesante es que los rostros visibles presentan, en lugar de los ojos, unas cruces, convención gráfica que suele utilizarse para indicar que un personaje está muerto. Este hecho contrastaría con la práctica que, según los testimonios, ocurrió en la realidad, ya que las personas eran lanzadas vivas, por lo que los autores estarían mostrando, en última instancia, un poco más de «compasión» que los militares (o simplemente que los querían bien muertos). También las ataduras que presentan los jueces dibujados remiten circunstancias históricas, como atestiguan las fotos de cuerpos hallados en la costa uruguaya ${ }^{44} \mathrm{La}$ búsqueda de justicia profesada por los organismos de DD. HH. se ve transmutada aquí en venganza pura y dura contra la propia Justicia, que irónicamente padece el violento y cruel accionar característico de aquellos a quienes ha beneficiado: se ha convertido en «el burlador burlado». Aquí la irreverencia no aparece mediada por un enunciador interno al chiste (no hay, por ejemplo, un personaje que en estado de emoción violenta diga «hay que matarlos a todos» o algo por el estilo): solo aparece el logo de Alegría y la firma de los autores.

La ignorancia histórica de Macri (ejemplificada en la escena escolar del cuadro de López y Agite que analizamos anteriormente) también aparece dibujada por Iván Riskin (Primer anuario, agosto) en un panel titulado «La dictadura vista por Mauricio M.». En él, un cartel anuncia «GGuerra sucia!» y se ve a Videla y a Hebe en una escena lúdica que representa la lucha en el lodo (dentro de una especie de pileta con forma

${ }^{42}$ En el señero libro El vuelo (1995) de Horacio Verbitsky, el represor Adolfo Scilingo admite la existencia de estos vuelos, a los que ya aludía Rodolfo Walsh en su Carta abierta de un escritor a la Junta Militar de 1977.

${ }^{43}$ En fallo dividido, convalidaron la medida Elena Highton de Nolasco, Carlos Rosenkrantz y Horacio Rosatti, mientras que se opusieron Ricardo Lorenzetti y Juan Carlos Maqueda; véase TARricoNE, M. «Fallo de la Corte Suprema: ¿qué es el “2x1"», 3 de mayo de 2017. Disponible en: https:// chequeado.com/el-explicador/fallo-de-la-corte-suprema-que-es-el-2x1/. Véase también el texto de Hauser, I. «La historia secreta del fallo del 2x1», en Página/12, 28 de julio de 2019. Disponible en: https://www.pagina12.com.ar/208789-la-historia-secreta-del-fallo-del-2-x-1. En el ya mencionado chiste de Giraldez y Podeti (10/5/2017), aparecen con su apellido los tres que estuvieron a favor, y también en un cuadro de Maléfico (10/5/2017) se caricaturiza de modo reconocible a esos mismos jueces apoyados sobre un Falcon verde con una actitud entre relajada y desafiante.

${ }^{44}$ Dandan, A. «Imágenes que prueban los vuelos de la muerte», en Página/12, 15 de diciembre de 2011. Disponible en: https://www.pagina12.com.ar/diario/elpais/1-183431-2011-12-15.html 


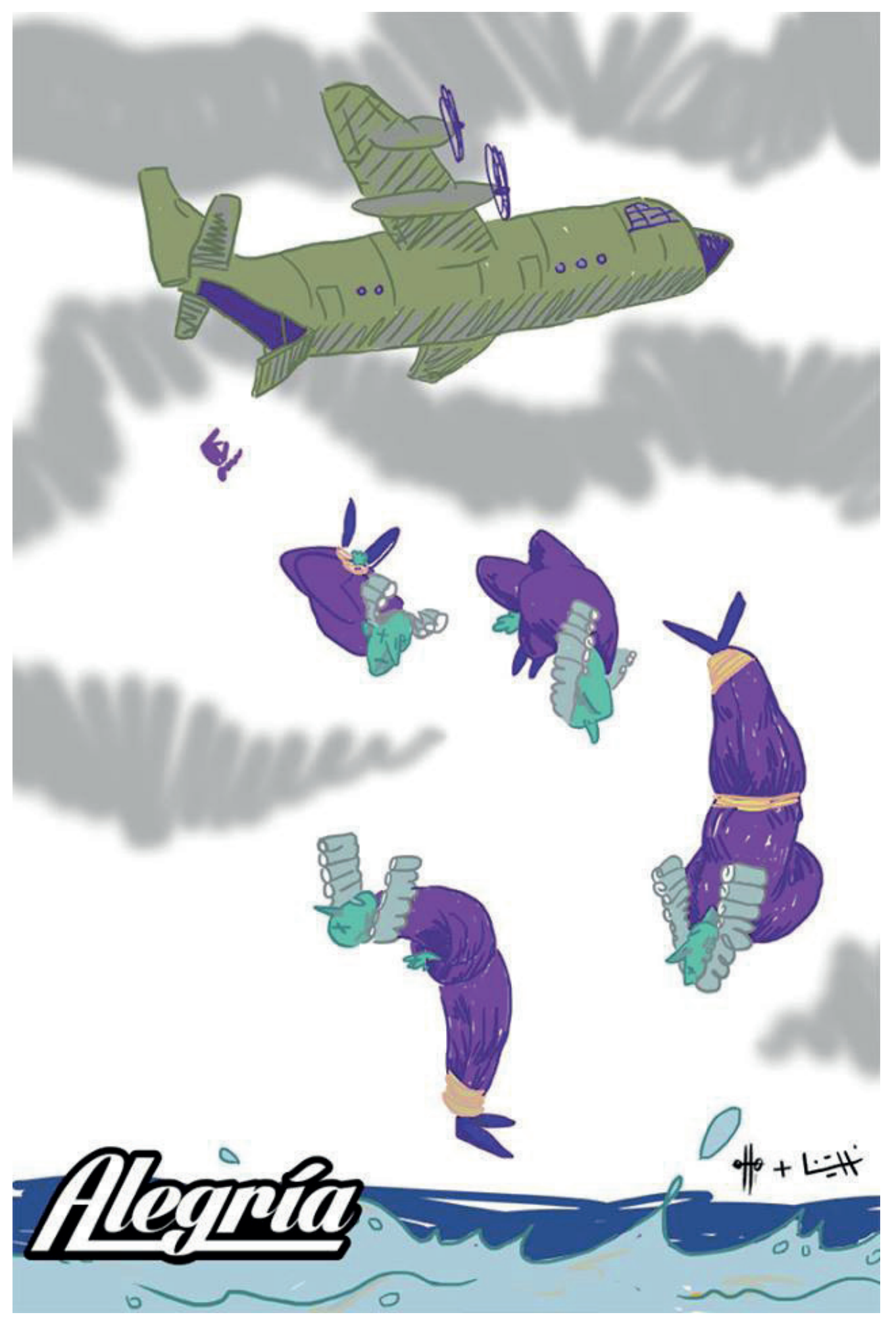

FIG. 9. Alegría politica, 2017, Otto y Lietti. 
de ring de boxeo). Hebe, con el pañuelo y un corpiño o bikini, dice con una sonrisa: «Tomá Videla!», mientras le arroja una bola de barro; el dictador, riéndose (con una risa también juguetona: «ji ji ji ji ja»), le pide: «No tires lodo en la cara, Hebe!». ${ }^{45}$ En esta visión de la historia atribuida a Macri, Riskin juega a su vez con diversas cuestiones: por un lado, con la lectura «literal» (infantil) del sintagma "guerra sucia» (que hay que entender, en realidad, como «terrorismo de Estado»); por otro, con la inversión del ejercicio de la violencia en esa guerra sucia: es Hebe (la civil) la que ataca a Videla (el militar), mientras que este solo atina a defenderse cubriéndose con las manos y pidiendo «clemencia». Se retoma así el señalado carácter combativo de Hebe (en las obras de Maléfico y Langer), ${ }^{46}$ como si fuera ella quien no respeta los códigos de esa «guerra» (no tirar barro en la cara) o la que «comete excesos». Dado que el lugar de la enunciación interna es ocupado por Macri, la irreverencia al interpretar el pasado se desplaza hacia su figura.

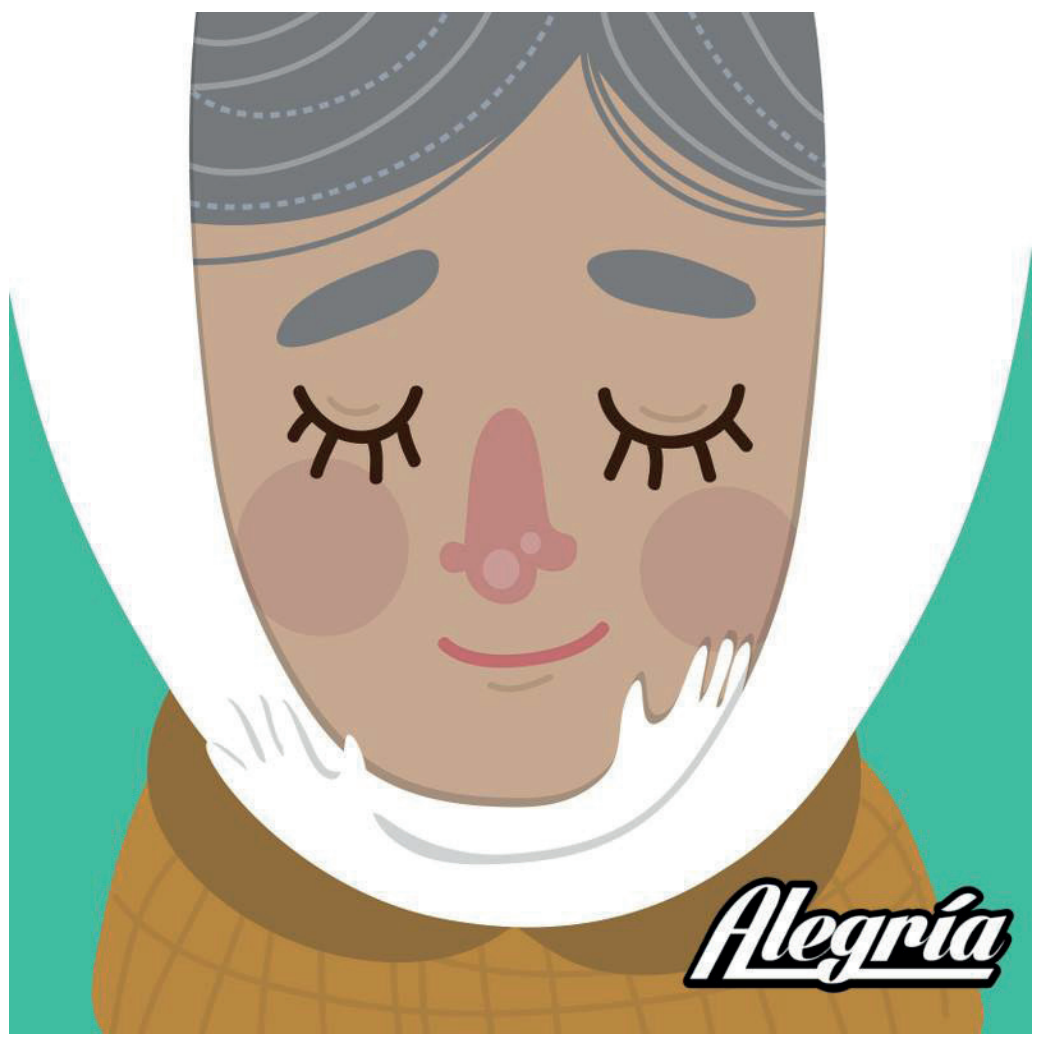

FIG. 10. Alegría politica, 2017, Tatiana

Pollero.

${ }^{45}$ El dibujo «sucio» de Riskin quizás hace necesaria esa identificación de los personajes intervinientes, porque no se trata de caricaturas reconocibles; al mismo tiempo, la utilización del apellido de Videla como vocativo por parte de Hebe parece resaltar su distancia o falta de «empatía» durante el juego (para reforzar su «violencia»), mientras que él se dirige a ella por su nombre, marcando cercanía.

${ }^{46}$ De hecho, en el Primer anuario las tres imágenes aparecen en páginas sucesivas. 
El símbolo del pañuelo blanco, como adelantamos, es también utilizado como recurso. Algunos trabajos articulan su forma con una función de encuentro (los «abrazos» con los que se contabilizan los nuevos nietos recuperados) y de contención social (como el de Tatiana Pollero, 26/3/2017, FIG. 10). Son piezas que apelan más a la reflexión que a la risa, que tienen más recursos de la ilustración que del humor gráfico en sí y que en ningún caso intentan generar controversia hacia los temas que abordan. En este punto, encontramos un límite muy definido, entendemos que marcado por la afinidad ideológica de la línea editorial del sitio. El pañuelo blanco, aquí, es absolutamente cuidado en su condición de símbolo. No obstante, el rechazo de Macri a las políticas de DD. HH. puede verse representado, justamente, a través de una metonimia que recurre a la mención del pañuelo, en la versión que Otto (10/7/2017,

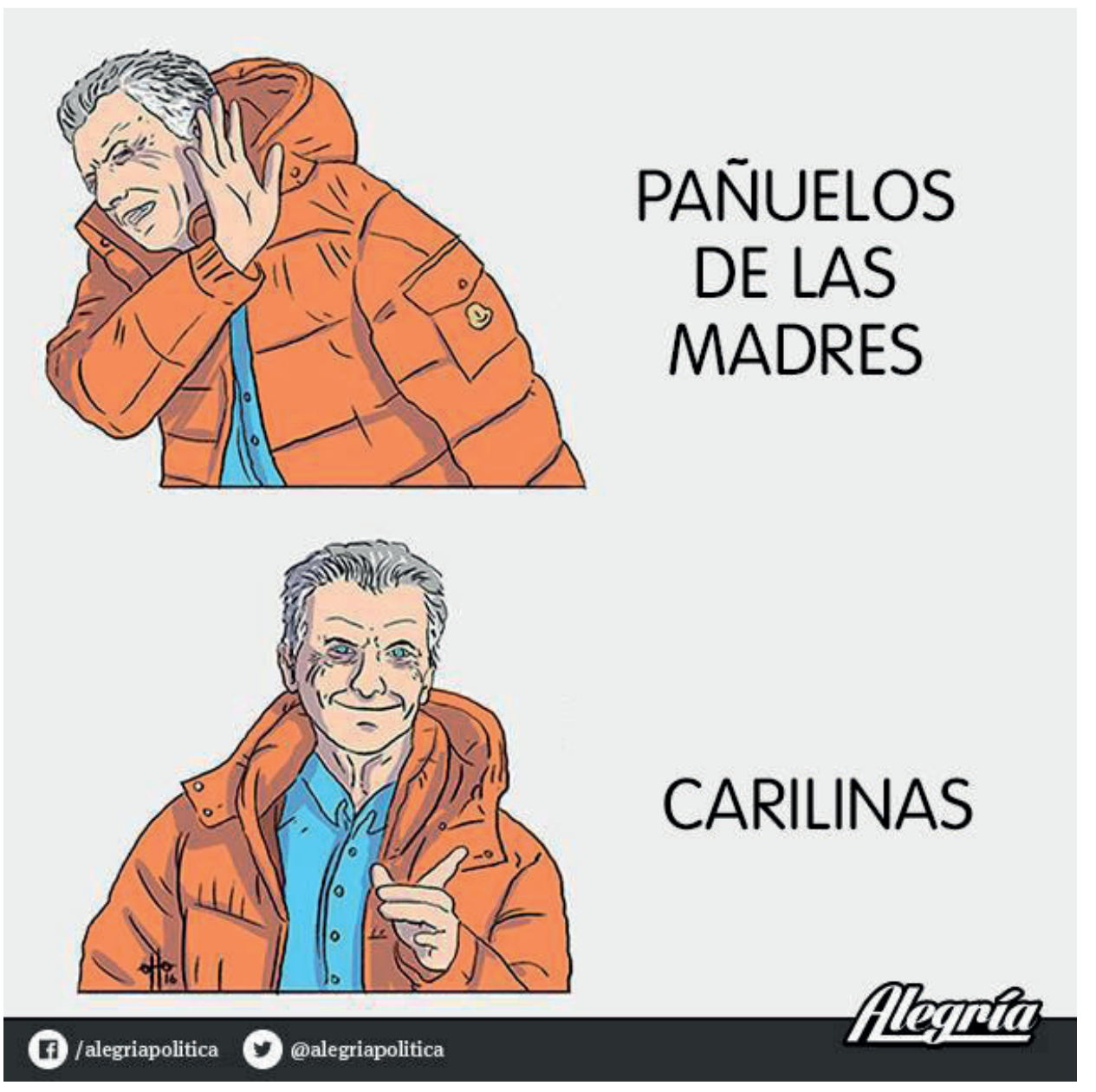

FIG. 11. Alegría politica, 2017, Otto.

día de la marcha contra el 2x1, FIG. 11) realiza del célebre «meme de Drake» (gesto de rechazo: «pañuelos de las madres», gesto de aprobación: «carilinas»). Nuevamente se juega aquí con una comprensión literal o «infantil» por parte de Macri (como en 
la «guerra sucia» de Riskin): el «pañuelo» como objeto cotidiano (para limpiarse los mocos), como si el símbolo de las madres perdiera toda su fuerza política e histórica para el presidente «empresario» (representación típica de su figura en el imaginario popular, tanto por parte de quienes lo apoyan como de quienes no) y le causara asco o repulsión, de modo que debería ser reemplazado por otro pañuelo (pero de papel y descartable, que además remite a una marca registrada, a una empresa). Aquí, como en el chiste de Riskin sobre la "guerra sucia», la irreverencia de relacionar el pañuelo blanco con una carilina se ve mitigada por atribuirle la responsabilidad de la enunciación a Macri (aunque eso hace a parte de la comicidad de ambos cuadros). Es decir, un chiste que contiene una importante dosis de humor negro se pone en boca de un personaje (o de una persona) que es percibido como alguien capaz de bromear con asuntos delicados, como un ignorante o como alguien que está en medio de esas dos posiciones: un hipócrita o un cínico.

En esta misma línea, un chiste de Langer (6/10/2016, Primer anuario) presenta a dos infiltrados a punto de sumarse a una marcha en una reconocible Plaza de Mayo del centro de Buenos Aires ${ }^{47}$ (se lee además un cartel con la leyenda «Nunca Más»), que podemos identificar como policías (mención de «una grande de muzzarella») o «servicios», camuflados con los pañuelos blancos, aunque usando sobretodos, anteojos negros y walkie-talkie. La acción alude a los incidentes ocurridos (provocados) en diversas marchas del primer año de gobierno de Macri y recupera también la figura de infiltrados o espías - como el capitán de fragata Alfredo Astiz - durante la última dictadura militar. A la vez, en un cuadro de Kripto (8/8/2016, Primer anuario) se contrapone la figura de un militar que marcha cargando un fusil a la de una mujer mayor que camina en dirección a él, llevando el pañuelo en la punta de un palo que se apoya en su hombro. Puede pensarse que aquí funcionan ambas representaciones del pañuelo, según del punto de vista que se considere. Por una parte, el gesto de la mujer parece remitir al de una viajera o caminante humilde, con una clara connotación pacifista en contraposición con el arma del militar: frente a las armas, el pañuelo; no la violencia, sino Memoria, Verdad y Justicia. Por otra, también puede aludir a la idea de empobrecimiento de las políticas de DD. HH. en la gestión Macri y al empobrecimiento económico de la sociedad en general, ${ }^{48}$ ya que el mismo autor (21/8/2016) realizará otro cuadro similar pero con dos hombres («linyeras», según se ve en sus vestimentas andrajosas): uno carga al hombro la «bolsita» típica en la punta de un palo (de color rojo) y el otro, un globo (amarillo).

${ }^{47}$ Histórica plaza situada frente a la Casa de Gobierno (Casa Rosada), habitual lugar de concentración de las manifestaciones y, los días jueves, de las marchas de Madres de Plaza de Mayo, con sus vueltas alrededor de la Pirámide, símbolo de la resistencia pacífica a la dictadura.

48 También aplicable a los organismos de DD. HH., ya que poco después, el 1 de octubre de 2016, se anunciaría un recorte del $12 \%$ en los fondos destinados al área en el presupuesto 2017; véase Ziblat, G. «El Gobierno reducirá un $12 \%$ los fondos para Derechos Humanos», en Perfil, 2 de octubre de 2016. Disponible en: https://www.perfil.com/noticias/politica/el-gobierno-reducira-un-12-los-fondos-para-derechos-humanos.phtml 
El tema de la desaparición y muerte de Santiago Maldonado tuvo un gran seguimiento dentro de Alegría. Casi siempre desde un explícito apoyo a los familiares y a la causa mapuche, y expresando una fuerte crítica a la política represiva de la gestión de la ministra de Seguridad de la Nación, Patricia Bullrich, se apunta al rol de los medios como encubridores y difusores de la demonización sobre la comunidad aborigen, sobre los manifestantes y sobre la juventud comprometida, en general. Un ejemplo es el trabajo de Cape titulado «El silenciador», publicado el 30 de agosto de 2017, en medio de la intensa búsqueda de Maldonado y las crecientes evidencias que señalaban como responsable a Gendarmería. Se muestra, justamente, a un gendarme colocando, en el caño de su arma, un ejemplar del diario La Nación enrollado a modo de silenciador, denunciando así la protección mediática a la gestión de la ministra Bullrich ${ }^{49}$ como extensión de la macrista (simbolizada otra vez en el color amarillo del círculo sobre el que está parado el gendarme).

\section{Conclusiones}

Una cosa es no hacerse ilusiones en la oscuridad o ante los titeres del espectáculo impuesto, y otra muy distinta doblegarse a este en la inercia mortifera de la sumisión, tanto si es melancólico como cínico o nibilista. ${ }^{50}$

Didi-Huberman, Insurrecciones

Al comenzar, nos hicimos algunas preguntas respecto del carácter provocador de Alegría y su posible domesticación, según formatos o tópicos tratados. En la selección de trabajos que analizamos, sucede algo interesante entre aquellos que se relacionan con el «pasado reciente»: el enemigo es siempre Macri y su gestión (incluyendo en ella al poder judicial). Esto marca una diferencia respecto de otros temas abordados (como el aborto legal, por poner un ejemplo contundente que merece un análisis aparte), ya que en lo referido a DD. HH. casi no hay ataques o cuestionamientos a la gestión anterior (tal vez el único ejemplo, minoritario en relación con otras figuras de Cambiemos, es el de César Milani), como tampoco se toca a agrupaciones de DD. HH. que, desde otros ámbitos de la prensa - tanto de derechas como de izquierdas-, han sido cuestionadas por supuestos malos manejos económicos o por las formas en las que algunos y algunas de sus representantes se expresan ante los medios (como el ejemplo ya señalado de Hebe de Bonafini o también hacia algunos integrantes de H.I.J.O.S. que cumplieron funciones públicas durante los años del kirchnerismo).

49 Ver también el chiste de Hor Lang y Mantrul (20/12/2017) parodiando una tapa del diario Clarín tras la represión policial durante las manifestaciones contra la reforma previsional (diciembre de 2017).

50 Didi-Huberman, G. Insurrecciones. Barcelona, Museu Nacional d'Art de Catalunya/Jeu de Paume, 2017, p. 16. 
Las piezas de humor que critican a la gestión macrista sobre DD. HH. parten de la parodia o la exacerbación de las características del mandatario y de sus ministros (su ignorancia, su desdén hacia el pueblo, su superficialidad, su violencia, su maldad) ante quienes los ciudadanos juegan el rol de víctimas o cómplices, exceptuando el chiste que compara los «vuelos de la muerte» con un posible castigo a los jueces actuales. Es esta quizá la pieza más impactante a nivel simbólico: plantea una salida del lugar de víctima a partir de la idea de venganza, de una «Ley del Talión» que choca con las consignas históricas de los organismos de DD. HH. en nuestro país. Interpretamos que este quiebre con un mandato clave de la posdictadura (no buscar venganza, sino justicia) tiene que ver con cierto hartazgo social y moral ante el constante avasallamiento de la gestión macrista hacia los DD. HH. y el avance de un discurso «reconciliador» que intentó obliterar las políticas de la memoria reciente.

Ante la intolerancia institucional y a la criminalización de la protesta social, hemos mencionado algunos trabajos que, usando como referente el caso de Santiago Maldonado, establecen comparaciones de estas políticas represivas del presente como continuidades o resurgimientos de aquellas prácticas de la época dictatorial. Algunas veces, ponen en cuestión la creencia de la «sociedad víctima» que se alentaba en la «Teoría de los dos demonios» y que el discurso macrista retomó desde 2016:51 tanto en el caso de Maldonado como en los trabajos sobre el 2x1, hay una interpelación al lector cuando se representa a algunos ciudadanos como desinteresados o cómplices de estos abusos policiales o militares. Creemos que se busca activar cierta conciencia política de los ciudadanos, como una advertencia de que la historia se puede repetir si no se asume un compromiso social.

Las líneas que analizamos en este trabajo (y otras que por falta de espacio no podemos desarrollar, como la frecuente utilización de la figura de Videla o la polémica por el número de desaparecidos) apuntan a una identificación del macrismo con la dictadura en múltiples aspectos, en sintonía con una percepción de ciertos sectores de la sociedad que se ha cristalizado en el cantito, muy popular en las manifestaciones, de «Macri, basura, vos sos la dictadura». En la historieta de dos páginas realizada por Langer y Rubén Mira (autores de la tira satírica La Nelly) para el Primer anuario,

${ }^{51}$ El caso más paradigmático es el del macrista Darío Lopérfido. En enero de 2016, cuando era Ministro de Cultura porteño, declaró: «En Argentina no hubo treinta mil desaparecidos, se arregló ese número en una mesa cerrada». Estela de Carlotto, presidenta de Abuelas, salió a responder: "Qué maldad empezar a manejar esta cifra. Si este señor considera que ese no es el número, que nos dé la lista de los que él piensa que son», aludiendo al silencio que los militares han mantenido hasta el presente respecto de las personas secuestradas y desaparecidas, a lo que agregó: «Nosotros manejamos esa cifra porque los propios depredadores lo llevaron a 45 mil. Hay montones de denuncias que no han quedado registradas porque hubo familias enteras que fueron diezmadas. Se registraron las denuncias como se pudo y todavía seguimos recibiendo denuncias de nietos nacidos en cautiverio». Véase S.a. «Lopérfido: "No hubo 30 mil desaparecidos, ese número se arregló en una mesa"», en La Política Online, 26 de enero de 2016. Disponible en: https://www.lapoliticaonline.com/nota/95544-loperfido-no-hubo-30-mil-desaparecidos-ese-numero-se-arreglo-en-una-mesa/. 
que funciona como una suerte de introducción o de prólogo, ${ }^{52}$ se narra «la génesis de Alegría en siete imágenes inolvidables para recortar y coleccionar», a la manera de una revista infantil que persigue un efecto irónico. Allí se van fechando distintos episodios de la historia argentina, que explicarían cómo se llegó al triunfo de Macri, todos protagonizados por Darth Vader (el villano de la saga Star Wars): 1920 Patagonia Rebelde (fusilamientos), 1930 década infame, 1955 bombardeo de Plaza de Mayo, 1973 Ezeiza, 1976 Junta militar (Darth Vader frente a un Falcon Verde y unos bigotudos de anteojos negros atrás), 2002 Kosteki y Santillán, 2016 [sic] elecciones nacionales. Se trata, más propiamente, de una genealogía, que ubica al macrismo como consecuencia y continuidad de momentos nefastos, violentos y antipopulares de nuestra historia.

En cuanto a la irreverencia, en particular, observamos que se presenta en algunos trabajos relativos al poder hegemónico gubernamental, judicial, eclesiástico y mediático y que, incluso, existen otras piezas que se atreven a cuestionar los mismos «lugares comunes» a los que interpelan como recurso referencial. Un ejemplo es el chiste de Otto, publicado el 9 de abril de 2017, dividido en dos cuadros, que presentan dos temporalidades: el primero (presente) muestra a un anciano con una banderita argentina en la mano, rodeado de amorosos corazones y supuestamente en una marcha, y, en off, un personaje dice: «Aww, iqué tierno el abuelo que apoya la democracia!». En el segundo cuadro, que nos muestra el pasado del personaje, vemos que se trata de un torturador, que dispara a una secuestrada que acaba de parir cautiva en un centro clandestino de detención y cuyo bebé está siendo robado por otro represor, según sugiere la imagen de fondo (FIG. 12). Leído en el marco de las protestas por el 2x1, viene a revisar la «candidez» con la que el imaginario social (y los medios, en particular) visibilizan a la vejez (enfatizando sobre el difundido término «abuelo», que interpela a lo emotivo), en especial sobre esa generación que hoy es vista como un grupo social desprotegido, aunque también ha sido partícipe, de diversas maneras, de ese pasado dictatorial que marca aún nuestro presente..$^{53}$

Otros trabajos, sin embargo, no persiguen una intención revulsiva: buscan construir una reflexión, una crítica gráfica a la política macrista. Como señalamos antes, son obras que no entran en la categoría de chiste propiamente dicha: se trata, más bien, de

52 El prólogo «oficial» es obra de Gustavo Sala e incluye una mala caricatura de Macri (el efecto es buscado, parte del chiste) que contrasta con la ilustración hiperrealista (aunque con un toque disruptivo en los ojos) que presenta la tapa.

${ }^{53}$ Dos chistes anteriores trabajaban ya con esta representación. Otro cuadro de Otto (Primer anuario, agosto) presenta, como un informe del Ministerio de Seguridad, dos figuras de ancianos contrapuestas: un «viejo malo» (jubilado) pidiendo «Queremos aumento!» y un «viejo bueno» (militar) pidiendo "Queremos domiciliaria». Anti (Primer anuario, agosto) utiliza el diseño del logo de Abuelas de Plaza de Mayo (con la leyenda «Identidad, familia, libertad») para crear, alterando palabras e imagen, el de Abuelos de Campo de Mayo — guarnición militar-(«Tortura, desaparición, opresión»). 

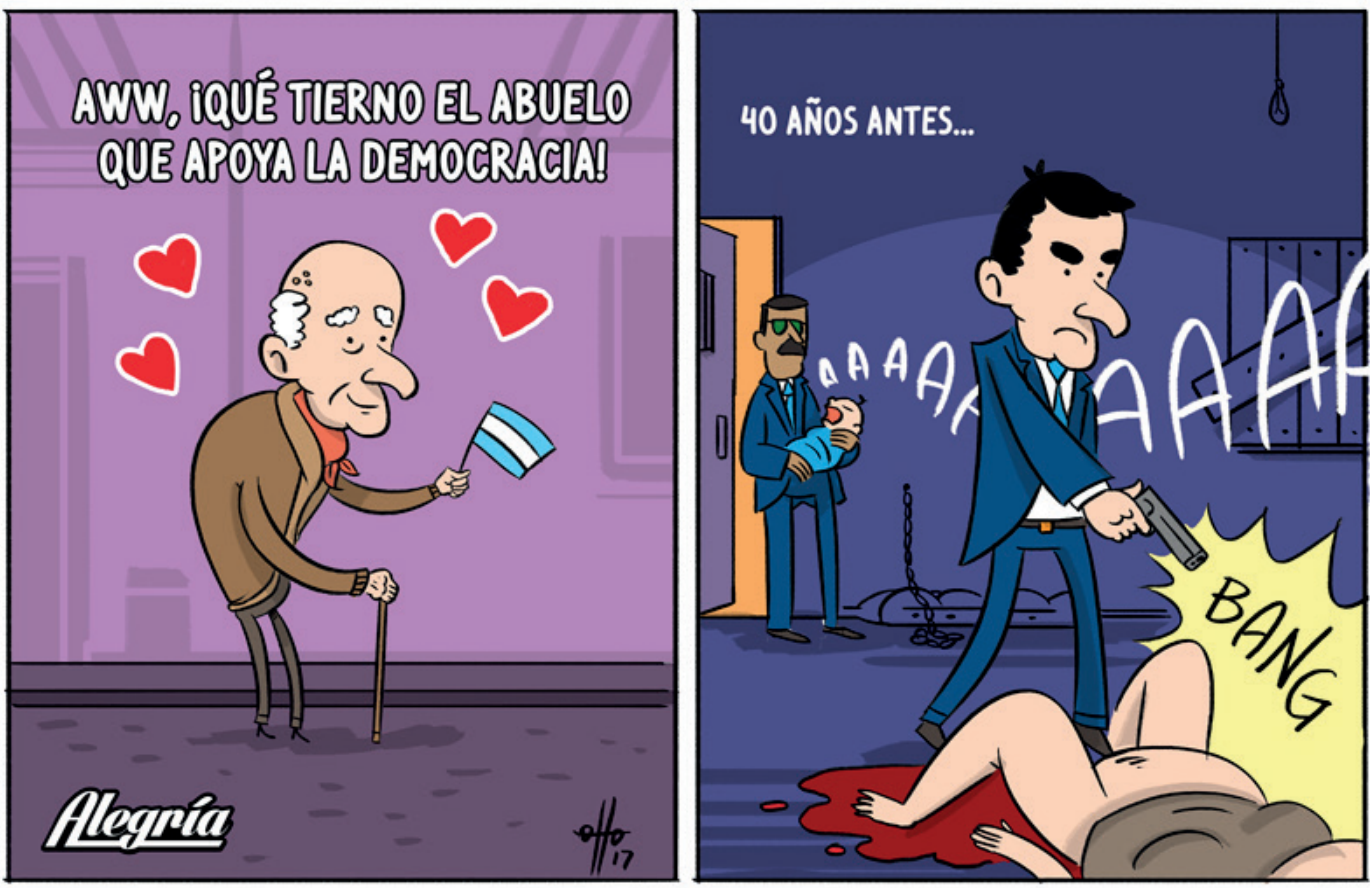

FIG. 12. Alegría politica, 2017, Otto.

ilustraciones referidas a lo coyuntural. En tal sentido, entendemos que quizá deben trabajarse como un subgrupo «no humorístico» dentro de las producciones de Alegría. También se vinculan estas al aspecto emotivo, que hemos señalado como un factor clave en el discurso general de este colectivo: lo experiencial, la vivencia traumática (la crisis económica que deriva en social y cultural, en hambre física e intelectual, en marginación o en un individualismo del «sálvese quien pueda») vuelve en forma de lectura crítica del pasado y del presente. No se trata, necesariamente, de un posicionamiento político partidario de los autores, sino más bien de una ideología crítica general hacia el neoliberalismo y sus consecuencias en la sociedad argentina (como anticipábamos, las violencias materiales y simbólicas que han quedado en la memoria colectiva y han marcado las prácticas sociales en la posdictadura).

Para retomar lo que planteamos en nuestras hipótesis tras lo analizado, observamos que, si bien en algunos aspectos particulares de cada pieza de humor pueden leerse tensiones entre lo contestatario y el «deber ser», Alegría, como propuesta editorial general, implica un discurso perturbador al relato dominante de Cambiemos. Tanto por ridiculizar (ampliamente) a las figuras más poderosas de ese gobierno, como por poner en cuestión al mismo extracto social de la clase media intelectual de la cual surge y a la cual se dirige; y por evidenciar las contradicciones o la hipocresía presentes en esas «creencias fundadas» de nuestra sociedad que, devueltas en forma de humor, se hacen más claras en su contradicción o perversidad. Podemos pensar que la tarea o rol sociopolítico y cultural de Alegría tiene que ver con intentar revisar y comprender, 
a través de una imagen-espejo mordaz, esas prácticas y «verdades» asumidas que llevaron al ascenso a un poder antipopular y destructivo.

Para finalizar, queremos destacar que este artículo fue escrito durante el último año de la gestión macrista a nivel nacional (2019), por lo cual el período seleccionado abarca un grupo de discursos de Alegría fuertemente marcado por ese primer impulso contestatario hacia las políticas neoliberales que intentaron desmantelar derechos sociales y estrategias de solidaridad comunitaria. «Con el diario del lunes», vemos cómo también dicho recorte temporal señala un proceso de paulatino desvelamiento social (parcial, por cierto) y de estrepitoso fracaso de dichas políticas.

Claramente, eso no implica que los integrantes de Alegría forman parte de un grupo de visionarios o clarividentes de la cultura popular, sino más bien que, al menos en ciertos sectores de la sociedad, el discurso de la «no-política», de la «reconciliación» y de la «apertura al mundo» ha sido resistido por motivos directamente vinculados con la memoria traumática sobre el pasado reciente, tengan matices partidarios o no. De este modo, se explica que el posicionamiento de muchos autores y autoras participantes de Alegría haya diferido en lo que respecta a simpatías con figuras políticas de la oposición a Cambiemos. Observamos que, a lo largo de estos cuatro años, fue armándose un temario hasta potenciarse un criterio general «antimacrista» que, en cierta forma, subsanó diferencias entre las posturas de izquierdas y las peronistas dentro del discurso general del colectivo.

La pregunta, hoy, es qué sucederá con este proyecto a futuro, si ese espíritu de resistencia al macrismo podrá reencausarse hacia otras figuras de los poderes gubernamentales posteriores a diciembre de 2019, si eso conllevará distanciamientos o renovaciones del staff de autores. Probablemente, tomando como referencia otras experiencias similares en el vasto prontuario de crisis socioeconómicas de la historia argentina, haya una revisión de los temas u objetos de crítica. Lo que puede apreciarse en el contexto de los primeros meses de gestión del Frente de Todxs (fines de 2019 y principios de 2020) es una serie de chistes en torno de tres focos: ataques al gobierno macrista saliente, críticas (aunque también apoyos) a algunas de las primeras medidas y acciones de la gestión del presidente Alberto Fernández (parodias de su figura sobre todo, y luego de Cristina Fernández, la vicepresidenta) y fuego cruzado entre izquierda y peronismo. Nos quedará, entonces, observar cuáles serán las respuestas de este colectivo en los tiempos venideros, teniendo en cuenta cómo supo colaborar con el imaginario de resistencia al macrismo y dio voz a algunas estrategias simbólicas que buscaron desactivar las creencias (nuevamente) alimentadas por el neoliberalismo en Latinoamérica. 


\section{Bibliografía}

Andrade, P. «Presentación», en Montealegre, J. et al. Un país de tontos graves. Humor gráfico y politica en Chile. Santiago de Chile, DIBAM/Museo Histórico Nacional, 2017, pp. 8-9.

Bajtin, M. Estética de la creación verbal. México, Siglo Veintiuno, 1999.

Boido, M. «Las artes y la construcción de la memoria», en Semilla Durán, M., Rosler, M. y Hernández, S. (ed.). Memoria de la ficción, ficción de la memoria: entre el ritual y la critica. Columbus, The Ohio State University, 2018, pp. 220-241.

Borobio, F. «Tras el cierre del suplemento de historieta argentina de Télam, el portal Recursos Culturales pondrá online todos sus contenidos», en Recursos culturales, abril de 2016. Disponible en: https://www.recursosculturales.com/cierre-suplemento-historieta-argentina-telam/

Burkart, M. De Satiricón a Humor. Risa, cultura y politica en los años setenta. Buenos Aires, Miño y Dávila, 2017.

Burke, P. Visto y no visto. El uso de la imagen como documento histórico. Barcelona, Crítica, 2005.

Chute, H. Disaster Drawn. Visual Witness, Comics, and Documentary Form. Cambridge, Harvard University Press, 2016.

Cirianni, E. et al. Alegría. Primer anuario. Buenos Aires, La Maroma Ediciones, 2017.

- Segundo anuario. Buenos Aires, La Maroma Ediciones, 2018.

- Tercer anuario. Buenos Aires, La Maroma Ediciones, 2019.

Dandan, A. «Imágenes que prueban los vuelos de la muerte», en Página/12, 15 de diciembre de 2011. Disponible en: https://www.pagina12.com.ar/diario/elpais/1-183431-2011-12-15.html

Didi-Huberman, G. Insurrecciones. Barcelona, Museu Nacional d'Art de Catalunya/Jeu de Paume, 2017.

Hauser, I. «La historia secreta del fallo del 2x1», en Página/12, 28 de julio de 2019. Disponible en: https://www.pagina12.com.ar/208789-la-historia-secretadel-fallo-del-2-x-1 
Hildebrandt, J. «Alegría: Dancin' in the Macrisis», en Comiqueando Online, 7 de noviembre de 2018. Disponible en: https://www.comiqueando.com.ar/notas/alegria-dancin-in-the-macrisis/

Levín, F. Humor politico en tiempos de represión (Clarín, 1973-1983). Buenos Aires, Siglo XXI, 2013.

Martignone, H. y Prunes, M. Historietas a diario. Las tiras cómicas argentinas de Mafalda a nuestros días. Buenos Aires, LIbraria, 2008.

Montealegre, J. Derecho a Fuga. Una extraña felicidad compartida. Santiago de Chile, Asterión, 2018.

Pertot, W. «Un rechazo que se convirtió en inmensa multitud», en Página/12, 11 de mayo de 2017. Disponible en: https://www.pagina12.com.ar/36972-un-rechazo-que-se-convirtio-en-inmensa-multitud

Rosenstone, R. Cine y visualidad. Historización de la imagen contemporánea. Santiago de Chile, Finis Terrae, 2013.

S.a. «La agencia Télam distribuye ahora historietas kirchneristas», en El Cronista, 15 de diciembre de 2011. Disponible en: https://www.cronista.com/informaciongral/ La-agencia-Telam-distribuye-ahora-historietas-kirchneristas-20111215-0056. html

S.a. «Lopérfido: "No hubo 30 mil desaparecidos, ese número se arregló en una mesa”, en La Politica Online, 26 de enero de 2016. Disponible en: https:// www.lapoliticaonline.com/nota/95544-loperfido-no-hubo-30-mil-desaparecidos-ese-numero-se-arreglo-en-una-mesa/

S.a. «Difunden que a Videla lo hallaron muerto en el inodoro de su celda», en Perfil, 18 de mayo de 2013. Disponible en: https://www.perfil.com/noticias/ politica/difunden-que-a-videla-lo-hallaron-muerto-en-el-inodoro-de-su-celda-20130518-0059.phtml

S.a. «Todo amarillo: el PRO y la mezcla entre propaganda y comunicación pública», en Télam, 16 de marzo de 2015. Disponible en: https://www.telam.com.ar/ notas/201503/98240-campana-pro-publicidad-comunicacion-institucional-amarillo.html

S.a. «Macri firmó la marcha atrás con el feriado del 24 de marzo», en Página/12, 1 de febrero de 2017. Disponible en: https://www.pagina12.com.ar/17492-macrifirmo-la-marcha-atras-con-el-feriado-del-24-de-marzo 
S.a. «Las Madres recordaron la "gambeta y jugada maradoniana" de Hebe de Bonafini para no ser detenida», en Secciones Bonaerenses, 5 de agosto de 2018. Disponible en: http://www.seccionesbonaerenses.com/nota.asp?n=unica\&id=27810\&id tiponota $=28$

Sasturain, J. «La nueva magia desaparecedora», en Página/12, 4 de abril de 2016. Disponible en: https:/www.pagina12.com.ar/diario/contrata$\mathrm{pa} / 13-296130-2016-04-04 . h t m l$

Tarricone, M. «Fallo de la Corte Suprema: ¿qué es el “2x1”», 3 de mayo de 2017. Disponible en: https://chequeado.com/el-explicador/fallo-de-la-corte-supremaque-es-el-2x1/.

Vezetti, H. Sobre la violencia revolucionaria. Memorias y olvidos. Buenos Aires, Siglo XXI, 2009.

White, H. Metahistoria. La imaginación histórica en la europa del siglo XIX. México, Fondo de Cultura Económica, 1992.

YbarRa, G. «El senado votó por unanimidad y es ley el límite al "dos por uno"», en La Nación, 11 de mayo de 2017. Disponible en: https://www.lanacion.com. ar/politica/el-senado-voto-por-unanimidad-y-es-ley-el-limite-al-dos-por-uno$\underline{\text { nid2022574 }}$

Ziblat, G. «El Gobierno reducirá un 12\% los fondos para Derechos Humanos», en Perfil, 2 de octubre de 2016. Disponible en: https://www.perfil.com/noticias/ politica/el-gobierno-reducira-un-12-los-fondos-para-derechos-humanos.phtml 